\title{
New Insights into the Synthesis and Biological Activity of the Pamamycin Macrodiolides
}

\author{
Gilles Hanquet ${ }^{\star a}$, Xavier Salom-Roig ${ }^{\mathrm{b}}$, and Steve Lanners ${ }^{\mathrm{c}}$
}

\begin{abstract}
After a brief account of the biological properties of pamamycins, this review highlights the latest developments on the total synthesis and the biosynthesis of these macrodiolides.
\end{abstract}

Keywords: Biosynthesis · Pamamycins - Total synthesis

The pamamycin family of macrodiolides, isolated from a variety of Streptomyces species, have attracted considerable attention from the scientific community over the last two decades due to their pronounced bioactivities and challenging molecular structures. Beside their aerial mycelium-inducing activity, they also enhance the production of secondary metabolites in several Streptomyces species and display antibacterial (active against Gram-positive bacteria) and antifungal activities. ${ }^{[1]}$ Since the isolation of a first member of pamamycin family with a molecular formula of $\mathrm{C}_{36} \mathrm{H}_{63} \mathrm{NO}_{7}$ and a molecular weight of 621 Da from Streptomyces alboniger by McCann and Pogell in 1979, [1a] a re-examination of extracts by Marumo and co-workers in 1987 showed a large number of homologs with various substituents in certain positions (Fig. 1).[2]

Structurally, the interesting features include a 16-membered macrodiolide and three cis-2,5-disubstituted tetrahydrofurans with adjacent methyl-substituted stereogenic centers, composed of two hydroxy acids, commonly called the 'larger' (C(1)-C(18), 2) and 'smaller' (C(1')$\mathrm{C}\left(11^{\prime}\right) 3$ ) fragments (Fig. 1). The attractive features and potential uses of pamamycins
${ }^{*}$ Correspondence: Dr. G. Hanquet ${ }^{a}$

aUniversité de Strasbourg

UMR CNRS 7509, ECPM

25 rue Becquerel, 67087 Strasbourg, France

E-mail: ghanquet@unistra.fr

bInstitut de Biomolécules Max Mousseron (IBMM)

UMR 5247, CNRS-Université de Montpellier

Place Eugène Bataillon, 34095 Montpellier, France

E-mail: salom-roig@univ-montp2.fr

cUniversity of Namur

Department of Chemistry and Namur Medicine \&

Drug Innovation Center (NAMEDIC)

61 rue de Bruxelles, 5000 Namur, Belgium

E-mail: steve.lanners@unamur.be have spurred attempts to provide sufficient amounts of macrolides to enable pharmacological application. Thus, numerous methods to chemically synthesize pamamycins as well as to use natural producers have been developed during the last decades. However, on the one side synthesis methods are complex and lengthy and on the other fermentation methods are limited by the low production level of the microorganisms used, and apart from the most abundant congener pamamycin 607 (1b), other homologues are obtained as mixtures from culture media. Recently, a pamamycin biosynthesis gene cluster has been identified ${ }^{[3]}$ and recombinant microorgan- isms have been developed for the production of pamamycins, in particular pamamycins 607 (1b) and 621A (1c). ${ }^{[4]}$ This account will cover synthetic work described since 2005 as well as recent findings on the biological activity of the pamamycins and the studies on their biosynthesis. ${ }^{[5]}$ Additional synthetic approaches to the constituent hydroxycarboxylic acids ${ }^{[6]}$ will not be detailed in this account.

\section{Total Synthesis}

The first efforts related to the total synthesis of the pamamycins were disclosed

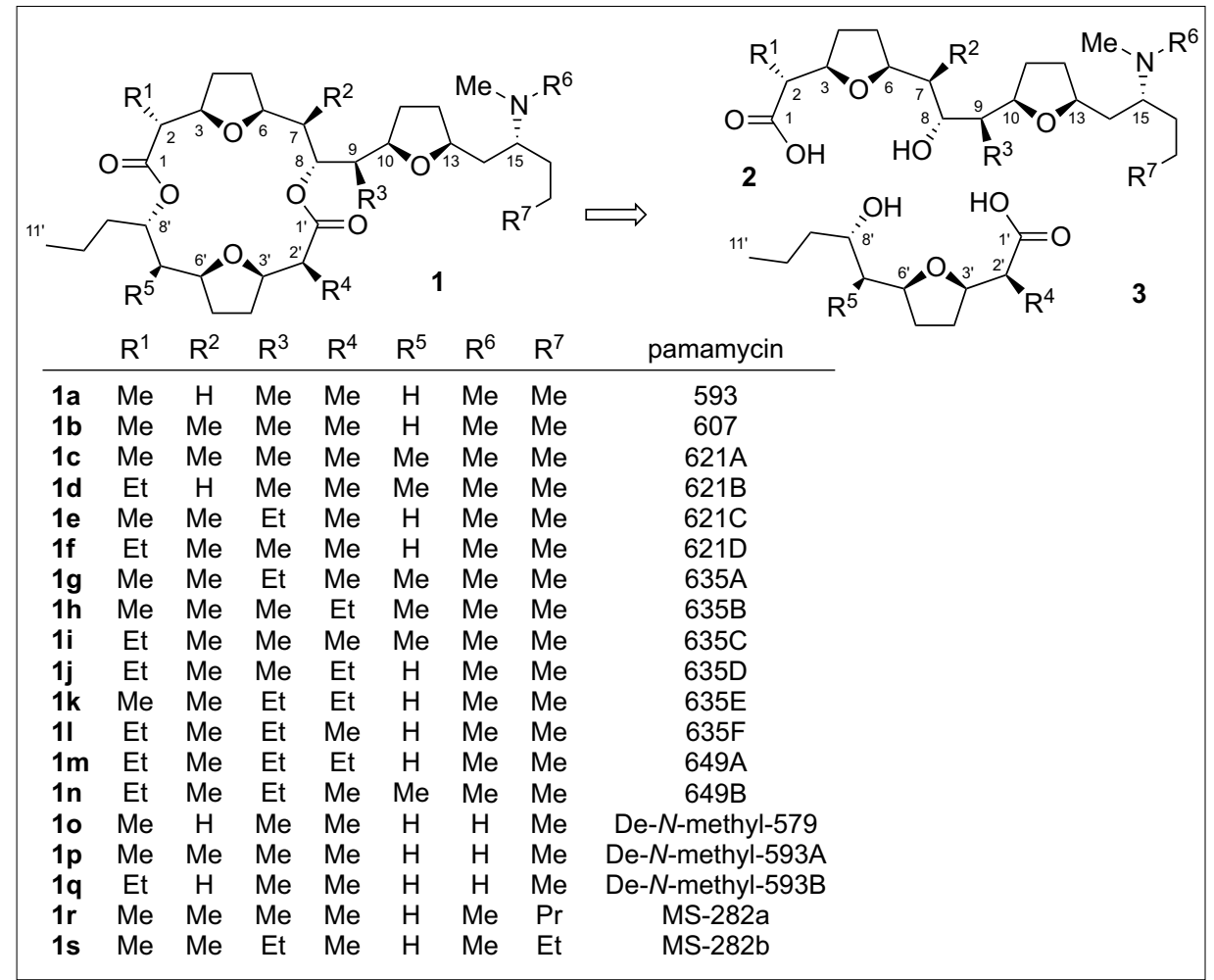

Fig. 1. The pamamycin macrodiolides and their hydroxy acid constituents 2 ('larger fragment') and 3 ('smaller fragment') 
in 1988. [7] However, even though several groups embarked on studies towards a total synthesis, none was described during the 1990s. Stereocontrol of the tetrahydrofuran rings and the adjacent stereogenic centers in the fragments $\mathbf{2}$ and $\mathbf{3}$ proved quite difficult and the first total synthesis was described by E. J. Thomas et al. in 2001. ${ }^{[8]}$ Then, three other elegant total syntheses along with various synthetic approaches to the hydroxy acid constituents 2 ('larger fragment') and $\mathbf{3}$ ('smaller fragment') of the pamamycins emerged and have been reviewed in two accounts in 2005. [5] However, most studies were directed toward pamamycin 607 (1b), the major homolog extracted from the natural source, and total synthesis towards some of the other molecules only appeared after 2005 .

\section{Metz Total Synthesis of Pamamy- cins 621A (1c), 635B (1h) and 649B (1n) $[9,10]$}

P. Metz slightly modified his elegant sultone route developed for the synthesis of pamamycin $607(\mathbf{1 b}),{ }^{[5]}$ to prepare homologs 621A (1c) and 635B (1h) differing only in terms of the smaller fragment $3\left(\mathrm{R}^{4}=\mathrm{Me}, \mathrm{Et}\right){ }^{[9]}$ and 649B (1n) differing only in terms of the larger fragment $2\left(\mathrm{R}^{1}=\mathrm{R}^{3}=\mathrm{Et}\right),{ }^{[10]}$ This approach was based on the stereoselective intramolecular Diels-Alder reaction of vinylsulfonates providing, via the pivotal sultones $\mathbf{4}$ and $\mathbf{5}$, silyl ethers $\mathbf{6 a}, \mathbf{b}$ of the hydroxy acids $\mathbf{2}$ and benzyl esters $\mathbf{7 a}, \mathbf{b}$ of the smaller fragments 3 epimeric at C(2') (Scheme 1). In the course of the total synthesis of $\mathbf{1 b}$, Metz had demonstrated that a complete $\mathrm{C}\left(2^{\prime}\right)$ epimerization of $\mathbf{7 a}$ occurred during the final Yamaguchi macrocyclization using Fleming conditions. ${ }^{[11]}$ Since fragment 7a was more easily accessible compared to its epimer $\mathbf{3}$, these macrocyclization conditions had been implemented successfully in a previous shortened total synthesis of pamamycin $\mathbf{1 b}$ and proved to be applicable to corresponding simplified routes towards other pamamycins.

The synthesis of the larger fragments 6a,b started with sultone $\mathbf{4}$ that had already been used as a precursor for pamamycin 607 (1b). ${ }^{[5]}$ The latter was reacted with two equiv. alkyllithium providing, via a domino elimination and alkoxide-directed 1,6 addition, the bicyclic compounds $\mathbf{8 a}$ as mixture of diastereoisomers and pure $\mathbf{8 b}$ (Scheme 2). Ozonolysis of the mixture $\mathbf{8 a}$ or pure $\mathbf{8 b}$ followed by eliminative workup, led to the formation of the two diastereoisomers 9a or pure 9b. Lewis acid-catalyzed substitution of the $\mathrm{OH}$ by a phenylthio group followed by treatment with Raney nickel in the presence of hydrogen gave 10a,b as single tetrahydrofurans. TBS protection followed by ester reduction and Appel reaction afforded the iodides $11 a, b$.

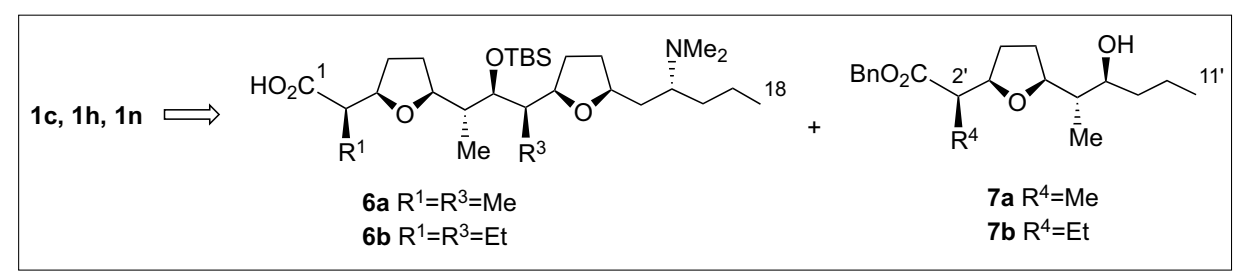

Scheme 1. Metz retrosynthetic analysis of 1c, 1h, 1n. TBS = tert-butyl-dimethylsilyl
Halogen-lithium exchange of iodides 11 and subsequent addition of 2-acetylfuran to the resultant organolithium intermediate yielded two diastereomeric tertiary alcohols, which were converted to $(E)$-olefins 12a,b with complete diastereoselectivity upon brief exposure to substoichiometric amounts of concentrated hydrochloric acid solution. Diastereoselective hydroboration/oxidation controlled by 1,3 -allylic strain of 12a,b gave largely the desired stereoisomers 13a,b. The hydroxy alkyl furans 13a,b were submitted to an addi- tional iteration of the sultone route based on the formation of a vinylsulfonate and an intramolecular Diels-Alder reaction to afford sultones $\mathbf{1 4 a}, \mathbf{b}$ as single diastereomers. Treatment of the latter with 2 equiv. of the appropriate alkyllithium led to the syn-selective introduction of a methyl or ethyl group via the previously described elimination/alkoxide-directed 1,6-addition and ozonolysis followed by treatment of the resulting mixture under eliminative conditions delivered the expected hemiketals $\mathbf{1 5 a}, \mathbf{b}$ as single stereoisomers. Treat-

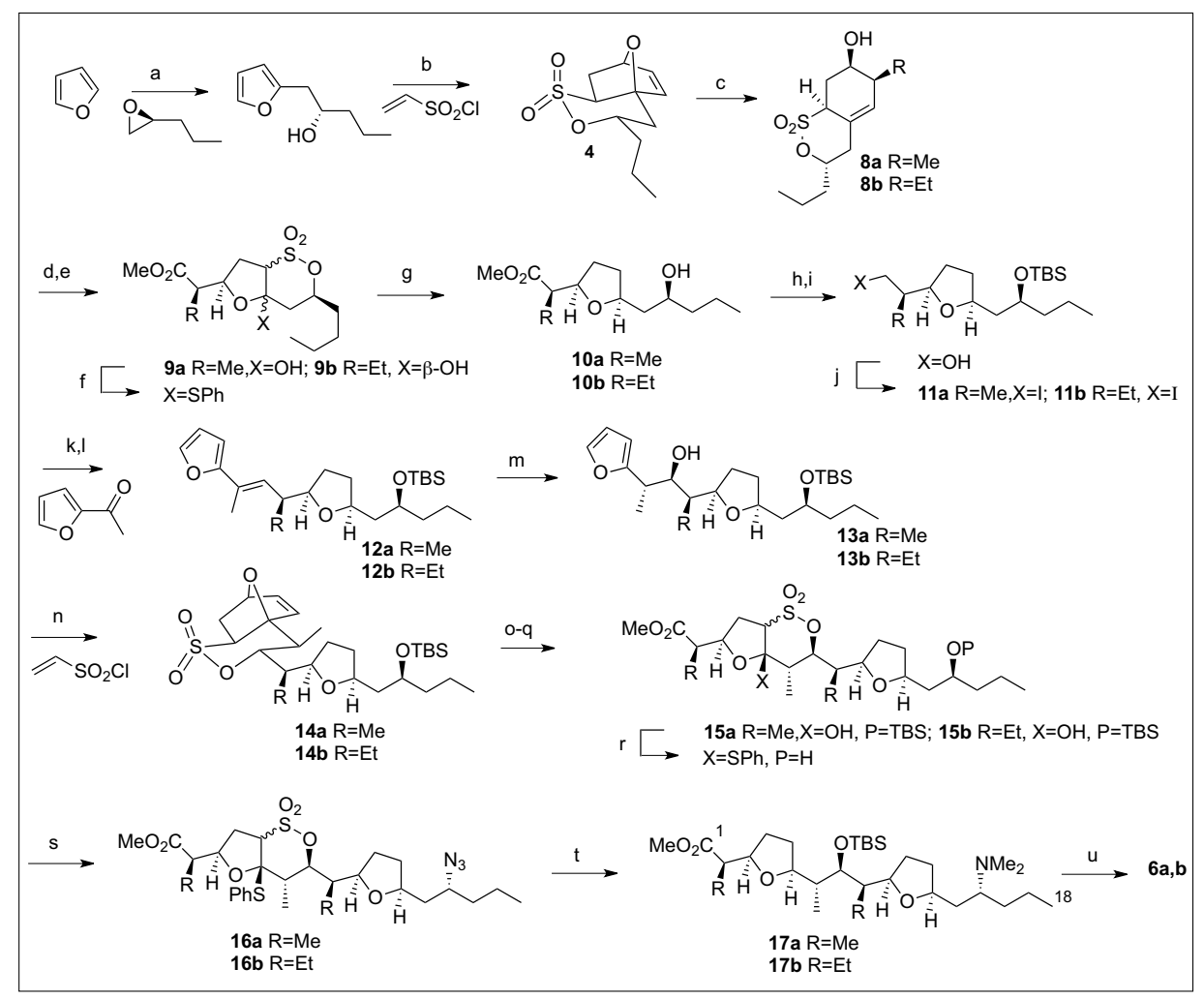

Scheme 2. Metz synthesis of the larger fragments $\mathbf{6 a}, \mathbf{b}$ of $\mathbf{1 b}, \mathbf{c}, \mathbf{h}, \mathbf{n}$. Reagents and conditions: a: (i) BuLi, THF, -78 to $-15^{\circ} \mathrm{C}$, (ii) (S) 1,2 -epoxypentane, $-15^{\circ} \mathrm{C}$ to $\mathrm{rt}, 84 \%$; b: vinylsulfonyl chloride, $\mathrm{Et}_{3} \mathrm{~N}, \mathrm{THF}, 0^{\circ} \mathrm{C}$ to rt, $88 \%$; c: (i) MeLi (for $8 \mathrm{a}$ ) or EtLi (for $\left.8 \mathrm{~b}\right) 2$ equiv., THF, -78 to $0{ }^{\circ} \mathrm{C}$; (ii) $\mathrm{NH}_{4} \mathrm{Cl}, \mathrm{H}_{2} \mathrm{O},-78^{\circ} \mathrm{C}$ to rt, $66 \% 8 \mathrm{a}, 36 \% 8 \mathbf{b}$; d: $\mathrm{O}_{3}, \mathrm{NaHCO}_{3}, \mathrm{CH}_{2} \mathrm{Cl}_{2}, \mathrm{MeOH},-78{ }^{\circ} \mathrm{C}$; e: $\mathrm{Ac}_{2} \mathrm{O}$, pyridine, $\mathrm{CH}_{2} \mathrm{Cl}_{2}$, rt for $9 \mathrm{a}$ or rt to reflux for $9 \mathrm{~b}, 83 \% 9 \mathrm{a}, 87 \% 9 \mathrm{9}$; f: $\mathrm{PhSH}, \mathrm{BF}_{3} \cdot \mathrm{Et}_{2} \mathrm{O}, \mathrm{CH}_{2} \mathrm{Cl}_{2}$, rt; g: Raney Ni (W2), 50 bar $\mathrm{H}_{2}$, EtOH, rt, $44 \%$ from 9 a for $10 a$, 33\% from 9 b for $10 \mathbf{b}$; h: TBSCl, imidazole, DMAP, DMF, rt; i: $\mathrm{LiAlH}_{4}, \mathrm{Et}_{2} \mathrm{O}, 0^{\circ} \mathrm{C}$ to rt; $\mathrm{j}: \mathrm{I}_{2}, \mathrm{Ph}_{3} \mathrm{P}$, imidazole, $\mathrm{Et}_{2} \mathrm{O}, \mathrm{MeCN}$, rt, $95 \%$ from 10a for 11a, and $94 \%$ from $10 \mathrm{~b}$ for $11 \mathrm{~b}$. $\mathrm{k}$ : (i) $t$-BuLi, $\mathrm{Et}_{2} \mathrm{O}$, hexane, $-78{ }^{\circ} \mathrm{C}$, (ii) 2 -acetylfuran, MS $4 \mathrm{~A},-78^{\circ} \mathrm{C}$ to rt; I: conc. aq. $\mathrm{HCl}, \mathrm{CHCl}_{3}$, rt, $69 \%$ 12a from 11a, $71 \% 12 \mathrm{~b}$ from 11b; m: (i) $\mathrm{BH}_{3} \cdot \mathrm{THF}, \mathrm{THF}, \mathrm{O}^{\circ} \mathrm{C}$ to rt, (ii) $30 \%$ aq. $\mathrm{H}_{2} \mathrm{O}_{2}, \mathrm{NaOH}, 0^{\circ} \mathrm{C}$ to rt, $65 \% 13 \mathrm{a}$ from $12 \mathrm{a}, 51 \% 13 \mathbf{b}$ from 12b; n: vinylsulfonyl chloride, $\mathrm{Et}_{3} \mathrm{~N}, \mathrm{THF}, \mathrm{O}^{\circ} \mathrm{C}$ to rt, $93 \%$ 14a, 88\% 14b; o: (i) MeLi 2 equiv., THF (for 14a) or EtLi 2 equiv., THF, Et $\mathrm{E}_{2} \mathrm{O}$, hexane (for 14b), -78 to rt; (ii) $\mathrm{NH}_{4} \mathrm{Cl}, \mathrm{H}_{2} \mathrm{O},-78{ }^{\circ} \mathrm{C}$ to rt; $\mathrm{p}$ : $\mathrm{O}_{3}, \mathrm{NaHCO}_{3}, \mathrm{CH}_{2} \mathrm{Cl}_{2}, \mathrm{MeOH},-78^{\circ} \mathrm{C}$; q: $\mathrm{Ac}_{2} \mathrm{O}$, pyridine, $\mathrm{CH}_{2} \mathrm{Cl}_{2}$, rt to reflux, 53\% 15a from 14a and $45 \% 15 b$ from 14b; r: PhSH, BF $\bullet \mathrm{Et}_{2} \mathrm{O}_{3} \mathrm{CH}_{2} \mathrm{Cl}_{2}$, rt; s: $\mathrm{HN}_{3}$, DEAD or DIAD (for 16b), $\mathrm{Ph}_{3} \mathrm{P}$, toluene, $0{ }^{\circ} \mathrm{C}$ to rt, $76 \% 16$ a from 15a, $75 \% 16$ from 15b; t: (i) Raney Ni (W2), 50 bar $\mathrm{H}_{2}$, EtOH, rt, (ii) aq. $\mathrm{CH}_{2} \mathrm{O}$, (iii) TBSOTf, 2,6-lutidine, $\mathrm{CH}_{2} \mathrm{Cl}_{2}$, rt, $50 \% 17 \mathbf{a}$ from $16 \mathbf{a}, 47 \% 17 \mathbf{b}$ from 16b; u: $\mathrm{LiOH}, \mathrm{THF}$, $\mathrm{MeOH}, \mathrm{rt}, 97 \%$ 6a, $41 \%$ 6b. DMAP $=4-(\mathrm{N}, \mathrm{N}-$ dimethylamino $)$ pyridine. 
ment of hemiketals $\mathbf{1 5 a}, \mathbf{b}$ with thiophenol and trifluoroborane led to the formation of a thioketal and concomitant removal of the TBS protecting group to afford the corresponding alcohol. The latter was converted into azides 16a,b under Mitsunobu conditions using hydrazoic acid. Subsequent treatment of 16a,b with Raney nickel under hydrogen pressure followed by addition of an aqueous formaldehyde solution effected the desired desulfurization, while also allowing the reduction of the azide into a primary amine, double methylation of the latter. The resulting alcohols were subsequently protected as TBS-ethers 17a,b. Finally, mild saponification of methyl esters 17a,b yielded the larger fragment coupling partners $\mathbf{6 a}, \mathbf{b}$.

A similar sultone-based strategy was applied to the synthesis of the $\mathrm{C}\left(2^{\prime}\right)$ epimeric smaller fragment benzyl esters of 1c,h,n as well (Scheme 3). Asymmetric hydroboration of the $E / Z(97 / 3)$ mixture of olefin 18, itself resulting from butyl Grignard addition/acid catalyzed elimination on 2-acetylfuran, led, after oxidative work up, to the anti-alcohol $19(81 \% e e)$ along with small amounts of the syn isomer. A subsequent reaction with vinylsulfonyl chloride induced a domino esterification/ intramolecular Diels-Alder reaction to give the pure exo-sultone $5(99 \%$ ee $)$ in $74 \%$ yield. Application of the domino reaction sequence of elimination/alkoxide-directed 1,6-addition, followed by sequential ozonolysis/cyclization, Lewis acid-catalyzed hydroxy/phenylthio exchange converted sultone $\mathbf{5}$ to thioethers $\mathbf{2 2 a}, \mathbf{b}$, which after a domino reductive elimination/hydrogenation and a dibutyltin oxide-catalyzed transesterification were transformed into benzyl esters $\mathbf{7 a}, \mathbf{b}$.

Having observed complete $\mathrm{C}\left(2^{\prime}\right)$ epimerization during their first total synthesis of pamamycin $\mathbf{1 b},[11 \mathrm{a}]$ the authors completed the total synthesis of pamamycins 1c,h,n using first an intermolecular Yamaguchi esterification of silyloxy acids $\mathbf{6 a}$ with benzyl esters $\mathbf{7 a}, \mathbf{b}$ leading

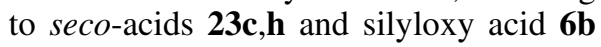
with benzyl ester 7a leading to seco-acid 23n. Finally, after deprotection of the

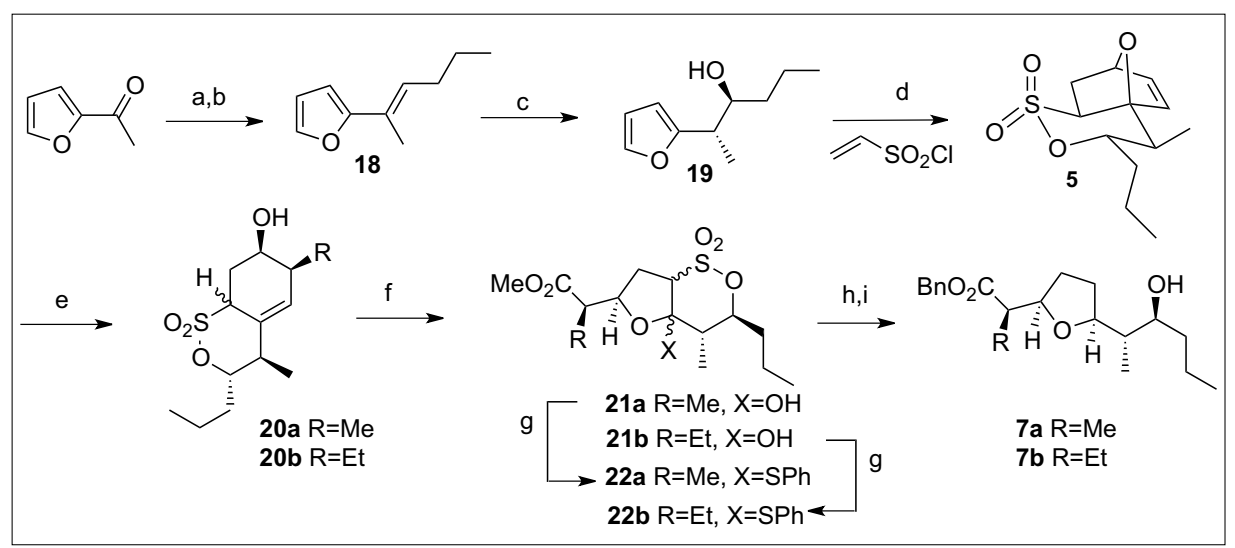

Scheme 3. Metz synthesis of the smaller fragments $\mathbf{7 a}, \mathbf{b}$ of $\mathbf{1} \mathbf{b}, \mathbf{c}, \mathbf{h}, \mathbf{n}$. Reagents and conditions: a: $\mathrm{BuMgBr}, \mathrm{Et}_{2} \mathrm{O}$, reflux; b: cat. $\mathrm{HCl}, \mathrm{CH}_{2} \mathrm{Cl}_{2}$, reflux, $58 \% 18$ from 2-acetylfuran, $E / Z=93: 7$; c: (i) IpcBH ${ }_{2}$ (derived from (+)- $\alpha$-pinene), $\mathrm{THF}_{2}-25{ }^{\circ} \mathrm{C}$, (ii) $\mathrm{H}_{2} \mathrm{O}_{2}, \mathrm{NaOH}, 70{ }^{\circ} \mathrm{C}, 76 \% 19(81 \%$ ee $)+$ syn isomer; d: (i) Vinylsulfone chloride, $\mathrm{NEt}_{3}, \mathrm{THF}, 0{ }^{\circ} \mathrm{C}$ to rt, (ii) recrystallization, $74 \% 5$ (99\% ee); e: (i) MeLi, 2 equiv. for $20 \mathrm{a}$, EtLi, 2 equiv. for $20 \mathrm{~b}$, THF, $-78^{\circ} \mathrm{C}$ to rt, (ii) $\mathrm{NH}_{4} \mathrm{Cl}, \mathrm{H}_{2} \mathrm{O},-78{ }^{\circ} \mathrm{C}$ to rt, $53 \%$ 20a, 68\% 20b; f: (i) $\mathrm{O}_{3}, \mathrm{NaHCO}_{3}, \mathrm{CH}_{2} \mathrm{Cl}_{2}, \mathrm{MeOH},-78^{\circ} \mathrm{C}$, (ii) $\mathrm{Ac}_{2} \mathrm{O}$, pyridine, $\mathrm{CH}_{2} \mathrm{Cl}_{2}$, rt to reflux, 87\% 21a, 86\% 21b; g: PhSH, BF . $_{2} \mathrm{Ot}_{2}, \mathrm{CH}_{2} \mathrm{Cl}_{2}, \mathrm{rt}, 79 \%$ 22a, 80\% 22b; h: Raney Ni (W2), 50 bar $\mathrm{H}_{2}$, EtOH, rt; i: $\mathrm{BnOH}, 10 \mathrm{~mol}_{\%} \mathrm{Bu}_{2} \mathrm{SnO}, 160^{\circ} \mathrm{C}, 55 \%$ 7a from 22a and $58 \% \mathbf{7 b}$ from 22b. $\mathrm{IpcBH}_{2}$ $=$ monoisopinocampheylborane.

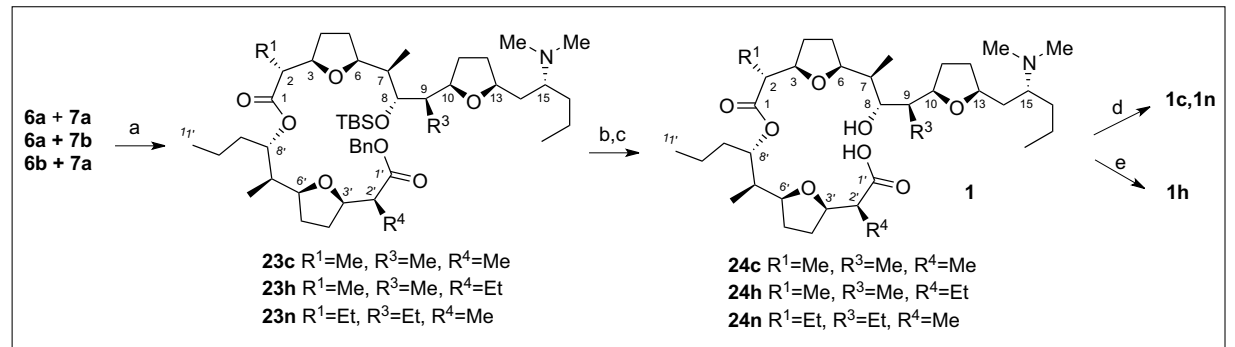

Scheme 4. Completion of Metz synthesis of pamamycins 1c,h,n. Reagents and conditions: a: (i) 2,4,6-trichlorobenzoyl chloride, $\mathrm{Et}_{3} \mathrm{~N}, \mathrm{THF}, 0{ }^{\circ} \mathrm{C}$ to rt, (ii) $\mathbf{7 a}$ or $\mathbf{7 b}$, DMAP, toluene, rt, $88 \% \mathbf{2 3 c}$, $78 \%$ 23h and $80 \%$ 23n; b: aq. HF, MeCN, rt; c: $\mathrm{H}_{2}, 10 \% \mathrm{Pd} / \mathrm{C}$, THF, rt, $97 \%$ 24c, $80 \%$ 24h and 95\% 24n; d: 2,4,6-trichlorobenzoyl chloride, DMAP, MS $4 \AA \mathrm{CH}_{2} \mathrm{Cl}_{2}$, rt, $64 \%$ 1c from 24c, 53\% $\mathbf{n}$ from 24n; e: (i) 2,4,6-trichlorobenzoyl chloride, $\mathrm{Et}_{3} \mathrm{~N}, \mathrm{THF}, \mathrm{O}^{\circ} \mathrm{C}$ to $\mathrm{rt}$, (ii) DMAP, toluene, reflux, $53 \%$ $1 \mathrm{~h}$ from $24 \mathrm{~h}$. MS = molecular sieves.

$\mathrm{C}(8)$ hydroxy group and $\mathrm{C}\left(1^{\prime}\right)$ carboxylic acid, modified Yamaguchi cyclization of 24c,n under Fleming conditions afforded pamamycin 621A (1c) ${ }^{[9]}$ and 649B (1n) $)^{[10]}$ as single diastereoisomers in good yields (Scheme 4).

Probably due to the greater steric hindrance caused by the $\mathrm{C}\left(2^{\prime}\right)$ ethyl group of seco-acid $24 \mathrm{~h}$, Yamaguchi lactonization was found to require a prior activation as a mixed anhydride followed by refluxing in toluene under high dilution conditions in the presence of DMAP. ${ }^{[9]}$ Using these conditions, pamamycin 635D (1h) was obtained in $53 \%$ isolated yield.

\section{Hanquet Total Synthesis of Pama- mycins 607 (1b) and $621 D(1 f)^{[12,13]}$}

A new total synthesis of pamamycin 607 (1b) was reported in 2007[12] by our own group and has been recently extended to pamamycin 621D (1f). ${ }^{[13]}$ Our approach

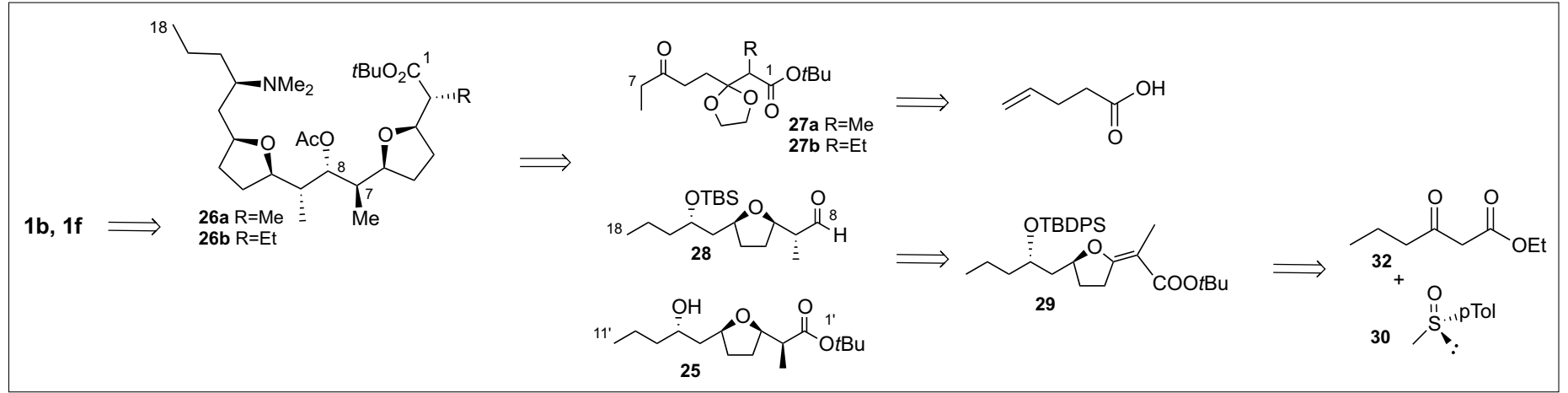


relied on the obvious disconnection of the two lactone linkages to afford the $\mathrm{C}\left(1^{\prime}\right)$ $\mathrm{C}\left(11^{\prime}\right)$ fragment 25 and the $\mathrm{C}(1)-\mathrm{C}(18)$ fragments 26a,b (Scheme 5). The $\mathrm{C}(7)$ $\mathrm{C}(8)$ bond was identified as an aldol retron and disconnected to obtain precursors 27a,b and 28.

This retrosynthetic analysis led to the proposal of a convergent approach in which three fragments of similar molecular weight, 25, 27 and 28, were to be joined at a late stage. Additionally, the observation that $\mathbf{2 5}$ and $\mathbf{2 8}$ were diastereoisomers differing by the configuration at $\mathrm{C}(2)$ and $\mathrm{C}\left(2^{\prime}\right)$ triggered the hypothesis of a common intermediate 29. An $E-Z$ isomerization followed by a cis-hydrogenation of the tetrahydrofuran-alkylidene double bond should lead to both fragments in a diastereodivergent manner. Common intermediate 29 was accessible using enantiomerically pure sulfoxide $\mathbf{3 0}$ as chiral auxiliary. ${ }^{[14]}$

Synthesis of the common intermediate 29 started with the $\beta$-ketosulfoxide 31 obtained from ethyl butyryl acetate (32) after formation of the dioxolane and a Claisen-type condensation with the anion of (-)-(S)-methyl- $p$-tolylsulfoxide (30, Scheme 6). ${ }^{[15]}$ DIBAL-H reduction and subsequent hydrolysis afforded the corresponding $[\mathrm{S}(S), 2(R)]-\beta$-hydroxysulfoxide 33 in $80 \%$ yield (de $>95 \%)$ which was subjected to an Evans reduction ${ }^{[16]}$ giving anti$[\mathrm{S}(S), 2(R), 4(S)]-\beta, \delta$-dihydroxy-sulfoxide 34 (de $>95 \%$ ), in $97 \%$ yield by crystallization. The reduction of the sulfoxide auxiliary, methylation at sulfur and intramolecular displacement of the sulfenium leaving group afforded the $[2(R), 4(S)]-\beta$-hydroxy epoxide 35 in $75 \%$ yield. Protection of the alcohol as TBDPS ether followed by a ring-opening with ethyl malonate anion and subsequent Krapcho-type decarboxylation afforded the lactone 36. Addition with the lithium enolate of $t$-butyl propionate to $\mathbf{3 6}$ produced a hemiketal which underwent an acid-catalyzed dehydration to afford the desired common intermediate 29 in $75 \%$ yield as a single thermodynamically preferred $E$ isomer.

$E-Z$ isomerization of $2^{\text {2917] }}$ was performed using LDA in the presence of $\mathrm{LiCl}$ and gave 37 in high yield.

Deprotection of either double bond isomer with TBAF and stereoselective hydrogenation on the more accessible face of the alkene using a $\mathrm{Rh} /$ alumina catalyst afforded the corresponding 2,5-cis-disubstituted tetrahydrofurans $\mathbf{3 8}$ and $\mathbf{2 5}$. Finally, protection of the hydroxy groups as TBS ethers and sequential transformation of $t$-butyl ester into an aldehyde led to fragment $\mathbf{2 8 .}$

Preparation of the second key step aldol addition partners $\mathbf{2 7 a}, \mathbf{b}$ started from commercially available 4-pentenoic acid (39) which was submitted to Claisen con-

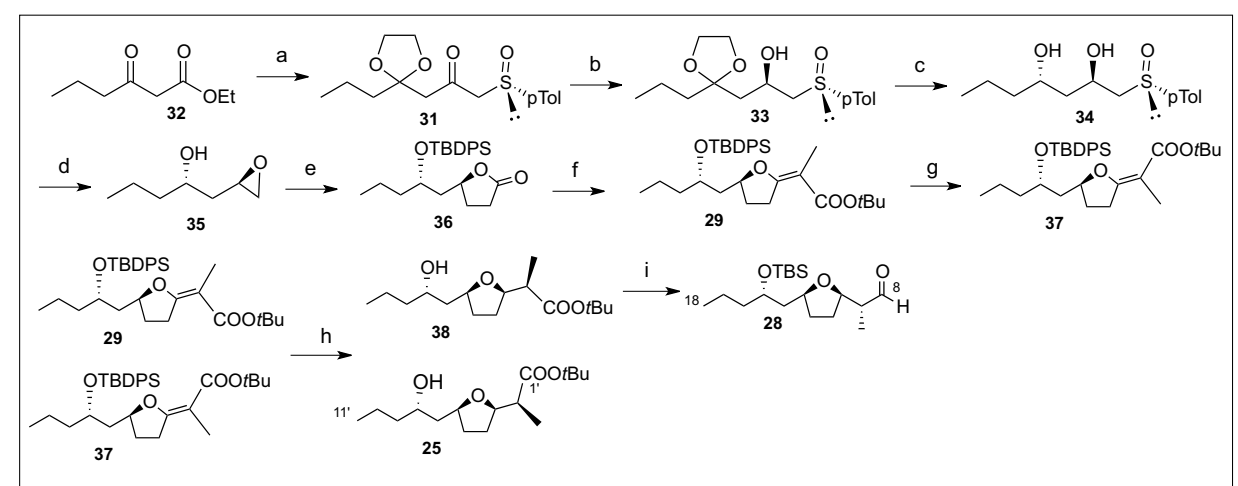

Scheme 6. Hanquet preparation of $\mathrm{C}(8)-C(18)$ and $C\left(1^{\prime}\right)-C\left(11^{\prime}\right)$ fragments 28 and 25 of pamamycin 607 (1b) and 621D (1f). Reagents and conditions; a: (i) Ethylene glycol, $\mathrm{TMSCl}, \mathrm{CH}_{2} \mathrm{Cl}_{2}$, rt; (ii) 31, LDA 2 equiv., THF, $-78{ }^{\circ} \mathrm{C}$ to rt, $60 \%$ for two steps; b: (i) Dibal-H, THF, $-78^{\circ} \mathrm{C}$, (ii) oxalic acid, THF/ water, $64 \% 33$ from 32 (de>95\%); c: $\mathrm{Me}_{4} \mathrm{NBH}(\mathrm{OAc})_{3}, \mathrm{AcOH}, 97 \%$ 34; d: (i) $t-\mathrm{BuBr}, \mathrm{CHCl}_{3}, 50{ }^{\circ} \mathrm{C}$, (ii) $\mathrm{Me}_{3} \mathrm{OBF}_{4}, \mathrm{CH}_{2} \mathrm{Cl}_{2}, 20^{\circ} \mathrm{C}$; (iii) $\mathrm{K}_{2} \mathrm{CO}_{3}, 75 \%$ 35; e: (i) TBDPSCl, imidazole, DMF, (ii) ethyl malonate, EtONa, THF, $-78^{\circ} \mathrm{C}$, (iii) $\mathrm{MgCl}_{2}-6 \mathrm{H}_{2} \mathrm{O}$, DMF, reflux, $73 \% 36$, f: (i) $t$-butyl propionate, LDA, THF, -78 ${ }^{\circ} \mathrm{C}$, (ii) oxalic acid, $\mathrm{CH}_{2} \mathrm{Cl}_{2}, 75 \%$ 29; g: LDA 2 equiv., LiCl 3 equiv., THF, then $\mathrm{EtOH}, 70 \%$ 37; h: (i) TBAF, THF, (ii) $\mathrm{H}_{2}, \mathrm{MeOH}, \mathrm{Rh}, \mathrm{Al}_{2} \mathrm{O}_{3}, 4$ bars, $73 \% 38$ and $67 \%$ 25; i: (i) TBSCl, imidazole, DMF, (ii) $\mathrm{LAH}$, ether, (iii) $\mathrm{SO}_{3}$-pyridine, Hunig base, $\mathrm{CH}_{2} \mathrm{Cl}_{2}, 89 \%$ 28. $\mathrm{LDA}=$ lithium diisopropylamide, TBAF: tetra-butyl ammonium fluoride. densation, via its acylimidazole derivative, with $t$-butyl propionate or $t$-butyl butanoate enolate to give ketoesters $40 a, b$ (Scheme 7). Protection of the ketone followed by epoxidation of the terminal double bond led to epoxides 41a,b. Finally ethyl ketones $27 \mathbf{a}, \mathbf{b}$ were obtained from the latter by ring-opening of epoxides and oxidation of the resulting alcohols.

With the larger fragment precursors $\mathbf{2 7 a}, \mathbf{b}$ and 28 in hand, a regio- and diastereoselective aldol addition using $\mathrm{Chx}_{2} \mathrm{BCl} /$ $\mathrm{Et}_{3} \mathrm{~N}^{[18]}$ was performed. An unusual behavior of ketones such as $\mathbf{2 7 a}, \mathbf{b}$ was observed, in that their enolization under boron-mediated conditions was shown to be strongly solvent-dependent. ${ }^{[19]}$ Whereas the use of pentane resulted in the formation of the undesired regioisomer 43a,b as the major product, the selectivity was reversed when diethyl ether was used as the solvent and, in these conditions, $\mathbf{4 2 a}$ and $\mathbf{4 2 b}$ were isolated as pure products in $52 \%$ and $61 \%$ yield respectively.

The preparation of the $\mathrm{C}(1)-\mathrm{C}(18)$ fragments 26a,b (Scheme 8) relied on an antiselective reduction of the $\beta$-hydroxyketone motif with concomitant differentiation of the two secondary hydroxyl groups; the use of the Tishchenko reduction using samarium(II) iodide as described by Evans ${ }^{[20]}$ allowed this transformation to give acetates $44 \mathbf{a}, \mathbf{b}$. Whereas the hydrolysis of the dioxolane under acidic conditions and the acid-mediated cyclization followed by TBS deprotection using Amberlyst 15 sulfonic acid resin afforded the unsaturated intermediate 45a efficiently, harsher conditions were required in the case of intermediate $\mathbf{4 4 b}$. In this case, hydrated iron(III) chloride adsorbed on silica gel was particularly efficient under microwave heating and cleanly cleaved the dioxolane group and triggered a cyclization-dehydration cascade with concomitant TBS deprotection to form the five-membered ring of intermediate 45b. A 2,5-cis-selective hydrogenation using the conditions described by Bartlett ${ }^{[21]}$ afforded intermediates 46a,b. The amine functional group was introduced using a Mitsunobu inversion of the secondary alcohol using hydrazoic acid or a safer alternative such as $\mathrm{PPh}_{3} / \mathrm{DEAD} /$ $(\mathrm{PhO})_{2} \mathrm{P}(\mathrm{O}) \mathrm{N}_{3}$, and the resulting azides

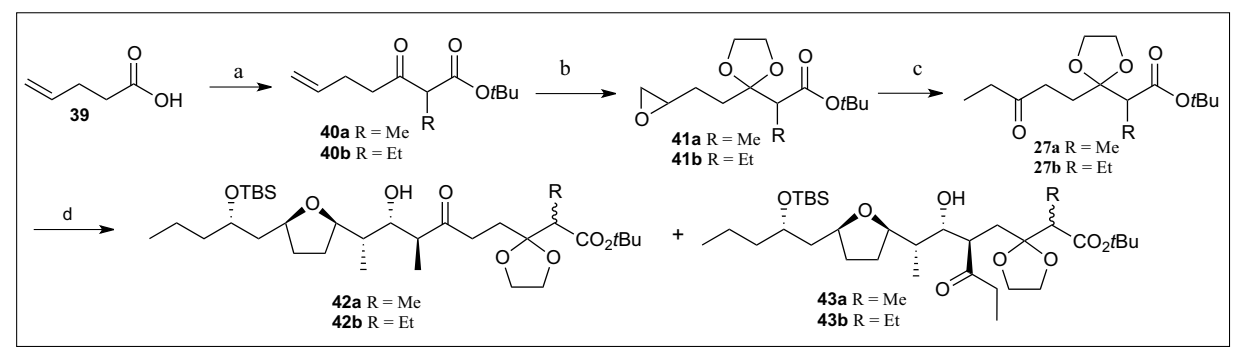

Scheme 7. Preparation of ethyl ketones 27 and aldolization key-step. Reagents and conditions: a: CDI, THF, rt, then $\mathrm{RCH}_{2} \mathrm{CO}_{2} t \mathrm{tBu}\left(\mathrm{R}=\mathrm{Me}\right.$, Et), LDA, $-78{ }^{\circ} \mathrm{C}, 91 \% 40 \mathrm{a}, 96 \% 40 \mathrm{~b}$; b: (i) $\left(\mathrm{CH}_{2} \mathrm{OH}\right)_{2}$, TEOF, CSA, rt, (ii) $m$-CPBA, $\mathrm{CH}_{2} \mathrm{Cl}_{2}$, rt, $58 \% 41 \mathrm{a}, 60 \%$ 41b; c: (i) $\mathrm{Me}_{2} \mathrm{CuLi}_{2} \mathrm{Et}_{2} \mathrm{O}, 0{ }^{\circ} \mathrm{C}$ (ii) PDC, DMF, rt, $92 \%$ 27a,b over two steps; d: $\mathbf{2 7 a}, \mathbf{b}, \mathrm{Chx}_{2} \mathrm{BCl}, \mathrm{Et}_{3} \mathrm{~N}$, solvent, $0{ }^{\circ} \mathrm{C}$, then $\mathbf{2 8},-78$ to -23 ${ }^{\circ} \mathrm{C}, 52 \%$ 42a, $61 \% 42 \mathrm{~b} \mathrm{Chx}_{2} \mathrm{BCl}=$ dicyclohexylboron chloride. $\mathrm{CDI}=$ carbonyl diimidazole, TEOF = triethylorthoformate, $m$-CPBA $=m$-chloroperbenzoic acid, $\mathrm{PDC}=$ pyridinium dichromate. 


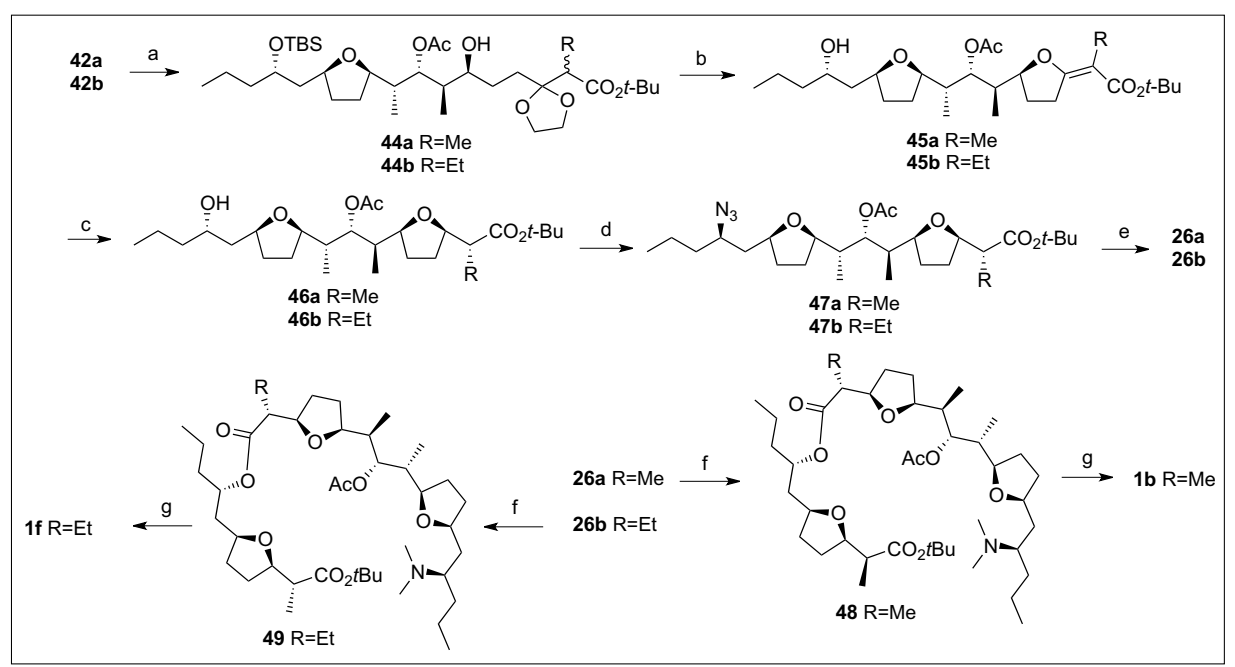

Scheme 8. Final steps completing the synthesis of pamamycin 607 (1b) and pamamycin 621D (1f). Reagents and conditions: a: $\mathrm{Sml}_{2}$ cat., $\mathrm{MeCHO}, \mathrm{THF},-10{ }^{\circ} \mathrm{C}, 59 \%$ 44a, $61 \%$ 44b; b: (i) oxalic acid, $\mathrm{CH}_{2} \mathrm{Cl}_{2}, \mathrm{H}_{2} \mathrm{O}$, (ii) TBAF, THF, rt, $78 \%$ 45a or $\mathrm{FeCl}_{3} \cdot 6 \mathrm{H}_{2} \mathrm{O} / \mathrm{SiO}_{2}, \mathrm{CHCl}_{3}$, microwave, 10 min, $71 \%$ 45b; c: $\mathrm{H}_{2}, 4$ bar, $\mathrm{Rh} / \mathrm{Al}_{2} \mathrm{O}_{3}, \mathrm{MeOH}$, rt, $90 \%$ 46a, $86 \%$ 46b; d: $\mathrm{HN}_{3}, \mathrm{PPh}_{3}$, DIAD, toluene, rt, $72 \%$ $47 a$, or (PhO) $\mathrm{P}(\mathrm{O}) \mathrm{N}_{3}, \mathrm{DIAD}_{3} \mathrm{PPh}_{3}$, THF, rt, 5h $86 \%$ 47b; e: $\mathrm{H}_{2}, \mathrm{Pd} / \mathrm{C}, \mathrm{HCHO}, \mathrm{AcOH}, \mathrm{MeOH}, \mathrm{rt}$, $85 \%$ 26a,b. f: (i) TFA, $\mathrm{CH}_{2} \mathrm{Cl}_{2}$, rt for 26a, or $\mathrm{MgBr}_{2}, \mathrm{CH}_{2} \mathrm{Cl}_{2}$ for 26b; (ii) 2,4,6- $\mathrm{Cl}_{3} \mathrm{PhCOCl}, \mathrm{Et}_{3} \mathrm{~N}$, THF, then 25, DMAP, toluene, $65 \%$ 48, or 2,4,6- $\mathrm{Cl}_{3} \mathrm{PhCOCl}$, $\mathrm{Et}_{3} \mathrm{~N}$, THF, then 38, DMAP, toluene, $75 \% 49$ g: (i) Lipase type VII, DMF, $\mathrm{H}_{2} \mathrm{O}$; (ii) $\mathrm{MgBr}_{2}, \mathrm{CH}_{2} \mathrm{Cl}_{2}$, (iii) 2,4,6- $\mathrm{Cl}_{3} \mathrm{PhCOCl}, \mathrm{DMAP}, \mathrm{CH}_{2} \mathrm{Cl}_{2}, 53 \% \mathbf{1 b}$, $60 \% 1 \mathrm{f}$ over three steps. TFA = trifluoroacetic acid, DIAD = diisopropyl azodicarboxylate.

47a,b were reduced by hydrogenation in the presence of $\mathrm{Pd} / \mathrm{C}$. The addition of formaldehyde to the hydrogenation reaction led to concomitant reductive amination to afford the fully functionalized $\mathrm{C}(1)-\mathrm{C}(18)$ fragments 26a,b.

The final sequence of steps towards pamamycin 607 (1b) followed the order established by the Metz group to avoid epimerization at $\mathrm{C}(2)$ during the Yamaguchi esterifications. ${ }^{[11]}$ Deprotection of tertbutyl ester 26a using trifluoroacetic acid and a first Yamaguchi reaction between the resulting acid and the small fragment $\mathbf{2 5}$ led to the seco-ester $\mathbf{4 8}$ in good yield (Scheme 8). The delicate removal of the acetate protecting group was performed using mild enzymatic conditions and saponification of the remaining tert-butyl ester led to the macrolactonization precursor, which was cyclized under Fleming conditions ${ }^{[11]}$ to $\mathbf{1 b}$ as pure macrodiolide.

In the course of our recent approach to pamamycin 621D (1f), we tried to avoid the lengthy and tedious column chromatography purification needed to separate the aldol addition product $\mathbf{4 2 b}$ from its regioisomers $43 \mathrm{~b}$ by preparing an unsaturated analogue of ketone $\mathbf{2 7}$, which should deliver only external aldol product (Scheme 9). The sequence started by the treatment of pentanenitrile under Pinner conditions, followed by reaction of the imidate intermediate with ethylene glycol to afford the orthoester 50. Bromination and subsequent base-promoted elimination afforded the desired orthoester $\mathbf{5 1}$ which was reacted with the silyl ketene acetal $\mathbf{5 3}$ derived from tert-butyl butanoate in the pres42b.
$\mathrm{DEAD} /(\mathrm{PhO})_{2} \mathrm{P}(\mathrm{O}) \mathrm{N}_{3}$ instead of $\left.\mathrm{HN}_{3}\right)$ compared to that used for 26a (Scheme 8) ${ }^{[12]}$ and the $\mathrm{C}(1)-\mathrm{C}(18)$ precursor of pamamycin 621D (26b) was isolated as pure product.

Deprotection of the tert-butyl ester in 26b and subsequent reaction with hydroxyester 38 was achieved leading to the formation of the seco-ester $\mathbf{4 9}$ in $\mathbf{7 5 \%}$ yield (Scheme 8). It is noteworthy that the use of fragment $\mathbf{3 8}$ leads to the formation of a seco-acid 49 that is epimeric to the natural product at $\mathrm{C}\left(2^{\prime}\right)$. However, it considerably shortens the overall length of the synthesis in that both the $\mathrm{C}(1)-\mathrm{C}(18)$ and $C\left(1^{\prime}\right)-C\left(11^{\prime}\right)$ fragments can be synthesized from the same precursors. The delicate deprotection of the acetate protecting group required the previously described use of mild enzymatic conditions to avoid side-reactions. ${ }^{[12]}$ This hydrolysis proceeded cleanly in $91 \%$ yield, while the subsequent removal of the tert-butyl group was quantitative. As previously described by Metz, ${ }^{[5,9,10]}$ macrolactonization under Fleming conditions leads to complete epimerization at $\mathrm{C}\left(2^{\prime}\right)$ and afforded pamamycin 621D (1f) in 60\% yield.

ence of zinc(II) bromide (1 equiv.) to give the protected $\beta$-ketoesters 52. The latter was converted into the more reactive terminal double bond via cross metathesis with ethylene. After the reaction was complete, ethylene was removed using several vacuum/argon cycles and ethyl vinyl ketone, carbene 56 and copper iodide were added to the reaction mixture leading to $\mathbf{5 4}$. Using previously published conditions for the enolization of $\mathbf{2 7 a}, \mathbf{b}$, aldol adduct $\mathbf{5 5}$ was obtained as pure enantiomer in $66 \%$ isolated yield, and subsequently reduced to the known fragment 42b. ${ }^{[12]}$

Finally, a slightly modified sequence was applied to the synthesis of $\mathbf{4 2 b}$ (ironcatalyzed deprotection/cyclization/dehydration of $44 \mathrm{~b}$ to prepare $\mathbf{4 5 b}$ and a Mitsunobu displacement from 46b using $\mathrm{PPh}_{3} /$

\section{Wu's Total Synthesis of Pamamycin $621 A(1 c)^{[22]}$}

Based on previous work on the synthesis of nonactic acid, ${ }^{[23]} \mathrm{Wu}$ and coworkers developed a convergent strategy towards the total synthesis of pamamycin 621A, using an Evans/Crimmins aldolization as key step, and intramolecular O-alkylation for the construction of the tetrahydrofuran rings. [24]

One more time, the macrodiolide core of 1c was first disconnected into the $\mathrm{C}(1)-$ $\mathrm{C}(18)$ (57) and $\mathrm{C}\left(1^{\prime}\right)-\mathrm{C}\left(11^{\prime}\right)$ (58) hydroxyacids. Fragment 57 was then further simplified into three key fragments, alkyne 59a, aldehyde 60 and enantiomerically pure acyloxazolidinone 61 (Scheme 10). Similarly, the smaller fragment $\mathbf{5 8}$ was

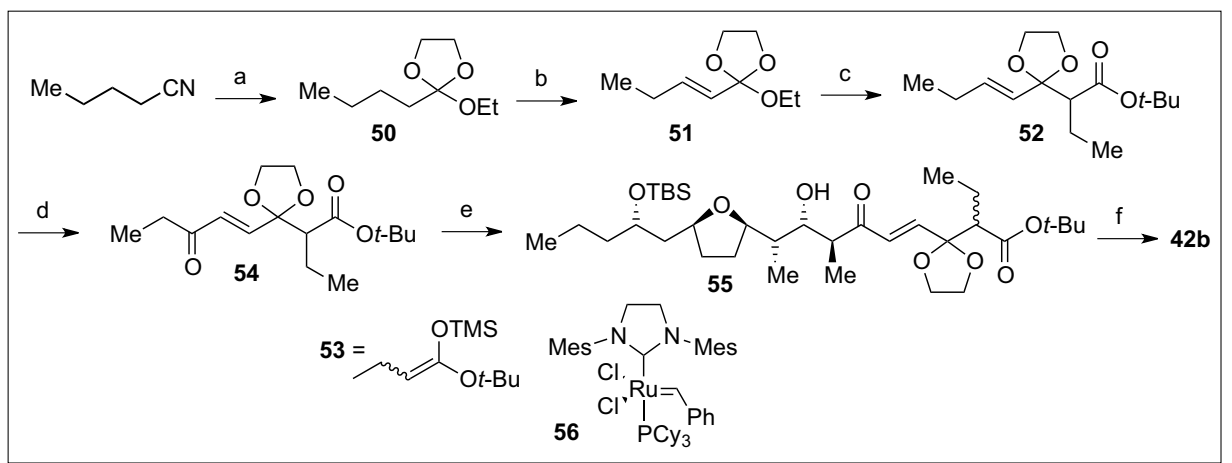

Scheme 9. Preparation of the unsaturated ethyl ketone $\mathbf{5 4}$ and its aldol condensation with aldehyde 28. Reagents and conditions: a: (i) $\mathrm{HCl}, \mathrm{EtOH}, \mathrm{i}-\mathrm{Pr}_{2} \mathrm{O},-20^{\circ} \mathrm{C}$, overnight, (ii) ethylene glycol, $\mathrm{HCl}, 24 \mathrm{~h}, 76 \%$ 50; b: (i) $\mathrm{Br}_{2}$ (0.5 equiv.), pyridine (1.1 equiv.), $\mathrm{CH}_{2} \mathrm{Cl}_{2}, 0{ }^{\circ} \mathrm{C}$ to rt, $24 \mathrm{~h}$, (ii) $t$-BuOK (1.2 equiv.), DMSO, $0{ }^{\circ} \mathrm{C}$ to rt, overnight, $72 \%$ 51; c: 53, $\mathrm{ZnBr}_{2}, \mathrm{CH}_{2} \mathrm{Cl}_{2}, \mathrm{rt}, 76 \%$ 52; d: $\mathrm{C}_{2} \mathrm{H}_{4}, 56$ (3 mol\%), toluene then (i) degas, (ii) ethyl vinyl ketone, 56 (5 mol\%), Cul (10 mol\%), 84\% 54; e: $\mathrm{Chx}_{2} \mathrm{BCl}, \mathrm{Et}_{3} \mathrm{~N}, \mathrm{Et}_{2} \mathrm{O}, 0{ }^{\circ} \mathrm{C}$, then $28,-78$ to $0^{\circ} \mathrm{C}, 66 \% 55 ; \mathrm{f}: \mathrm{H}_{2}, \mathrm{Pd} / \mathrm{C}(5 \%), \mathrm{NH}_{4} \mathrm{OH}, \mathrm{MeOH}, 88 \%$ 


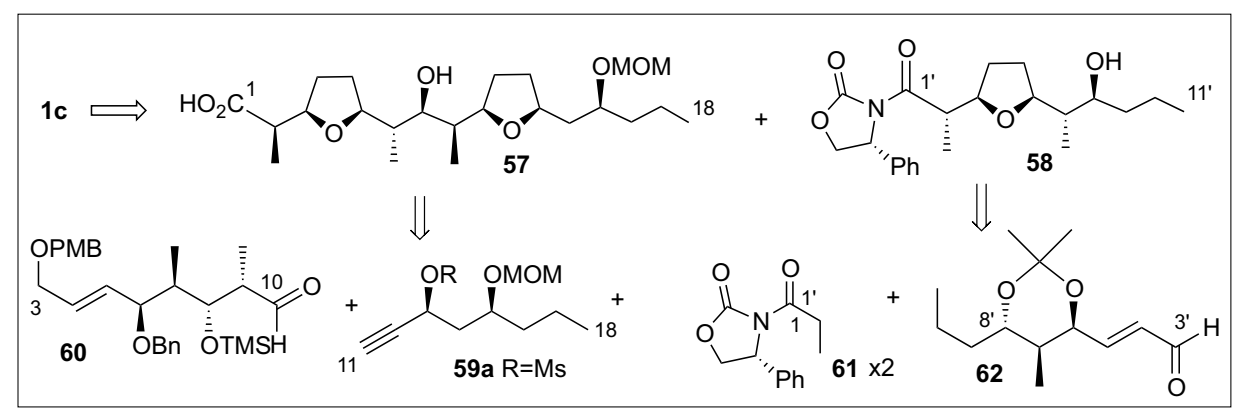

Scheme 10. Wu's retrosynthetic analysis of 1c.

retrosynthetically simplified via $\mathrm{C}-\mathrm{O}$ disconnection at the THF ring and the resulting polypropionate disconnected between $\mathrm{C}\left(2^{\prime}\right)-\mathrm{C}\left(3^{\prime}\right)$ into aldehyde $\mathbf{6 2}$ and the same acyloxazolidinone $\mathbf{6 1}$.

The preparation of $\mathbf{5 8}$ began with a Crimmins aldol addition between enal 63a and enantiomerically pure acyloxazolidinone 61 (Scheme 11). The resulting aldol 64 (dr 23:1) was reacted with $\mathrm{AlMe}_{3} /$ $\mathrm{MeNH}(\mathrm{OMe}) \cdot \mathrm{HCl}$ and $n$-PrMgBr sequentially to afford ketone $\mathbf{6 5}$. Treatment of $\mathbf{6 5}$ with $\mathrm{Me}_{4} \mathrm{NBH}(\mathrm{OAc})_{3}$ installed the $\mathrm{C}\left(8^{\prime}\right)$ stereogenic center and subsequent deprotection of the silyl ether and acetonide formation from the diol provided alcohol 66, which upon oxidation using the DessMartin periodinane produced aldehyde 62. In sharp contrast with literature, Evans aldol addition using aldehyde $\mathbf{6 2}$ was found to occur only if stoichiometric amounts of $\mathrm{MgCl}_{2}$ were present. Thus, $\mathrm{MgCl}_{2}$ (2 equiv.) / $\mathrm{Et}_{3} \mathrm{~N}$ (5 equiv.) in the presence of 3 equiv. of TMSCl and subsequent treatment with DDQ led to $\mathbf{6 7}$ in $56 \%$ overall yield. The alcohol $\mathbf{6 7}$ was converted into $\mathbf{6 8}$ by hydrogenation of the alkene, mesylation of the alcohol at $\mathrm{C}\left(3^{\prime}\right)$, and removal of the acetonide, affording the correct functionalization for the formation of the THF ring by intramolecular nucleophilic displacement with inversion at $\mathrm{C}\left(3^{\prime}\right)$. Thus, by heating 68 in neat pyridine at $110{ }^{\circ} \mathrm{C}$ for $3 \mathrm{~h}, \mathbf{5 8}$ was obtained in $63 \%$ yield as a single isomer.

According to the synthetic plan (Scheme 10), the more complex fragment 57 came from the double intramolecular O-alkylation of the linear intermediate 69 which was obtained from its precursors 59 (the $\mathrm{C}(11)-\mathrm{C}(18)$ fragment) and $\mathbf{6 0}$ (the $\mathrm{C}(3)-\mathrm{C}(10)$ fragment). Alkyne 59 was prepared according to Scheme 12 starting from the enantiomerically pure epoxide precursor 70. The latter ${ }^{[25]}$ was readily prepared from inexpensive $\mathrm{D}$-gluconolactone through a convenient route developed previously by $\mathrm{Wu}$ and coworkers. ${ }^{[26]} \mathrm{Ring}$ opening of 70 with $\mathrm{EtMgBr} / \mathrm{CuCN}$ in THF followed by protection of the alcohol as MOM ether led to fully protected polyol 71. Selective removal of the acetonide using $\mathrm{CF}_{3} \mathrm{COOH}$ in dichloromethane at am- bient temperature afforded the desired alkyne 59 after oxidative cleavage of the resulting diol and Corey-Fuchs alkynylation.

Fragment 60 was prepared using two asymmetric Evans/Crimmins aldol reacamine, DDQ: 2,3-dichloro-5,6-dicyano-1,4-benzoquinone. $\mathrm{MOMCl}=$ methoxymethyl chloride. tions to control the absolute configurations of the $C(6)-C(9)$ stereotetrad (Scheme 12). The first aldol condensation with enal $\mathbf{6 3 b}$ gave $\beta$-hydroxy carbonyl compound $\mathbf{7 2}$ and reductive cleavage of the chiral auxiliary followed by protection with benzaldehyde dimethyl acetal afforded $\mathbf{7 3}$ in $91 \%$ yield. Reduction of the acetal using DIBAL-H and oxidation of the resulting alcohol by the Dess-Martin periodinane afforded aldehyde $\mathbf{7 4}$. The chain was further extended by two carbons by an aldol addition of $\mathbf{7 4}$ with acyl-substituted oxazolidinethione $\mathbf{7 5}$ under Crimmins' conditions using (-)-sparteine as base. Protection of the alcohol in the aldol product $\mathbf{7 6}$ as a trimethylsilyl (TMS) ether (facilitating purification at a later stage) preceded the removal of the chiral auxiliary which

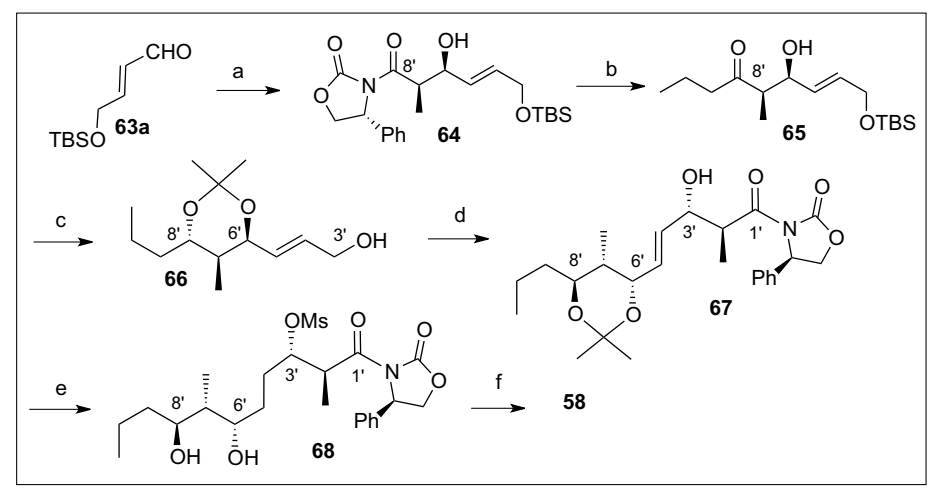

Scheme 11. Wu's preparation of the smaller fragment 58 of pamamycin $621 \mathrm{~A}(1 \mathrm{c})$. Reagents and conditions: $\mathrm{a}: 61, \mathrm{TiCl}_{4}, \mathrm{TMEDA}, 84 \% 64 \mathrm{dr}$ 23:1, b: (i) $\mathrm{MeNH}(\mathrm{OMe}) / \mathrm{AlCl}_{3}$, (ii) $n-\mathrm{PrMgBr}, 90 \%$ 65, c: (i) $\mathrm{Me}_{4} \mathrm{NBH}(\mathrm{OAc})_{3}$, $\mathrm{MeCN} / \mathrm{AcOH},-20{ }^{\circ} \mathrm{C}$, (ii) TBAF/THF, (iii) $\mathrm{MeC}(\mathrm{OMe})_{3} \mathrm{CSA}$, (iv) $70 \% \mathrm{AcOH}$, $75 \% 66$ from 65, d: (i) Dess-Martin periodinane, (ii) $61, \mathrm{MgCl}_{2}$ (2 equiv.), $\mathrm{Et}_{3} \mathrm{~N}$ (3 equiv.), TMSCI (3 equiv.), (iii) DDQ, THF/water, 56\% 67, e: (i) $\mathrm{H}_{2} /$ $\mathrm{Pd}-\mathrm{C}, \mathrm{Et}_{3} \mathrm{~N}, \mathrm{EtOAc}$, (ii) $\mathrm{Et}_{3} \mathrm{~N}, \mathrm{MsCl}, \mathrm{CH}_{2} \mathrm{Cl}_{2}, 1 \mathrm{~N} \mathrm{HCl}, \mathrm{THF}-\mathrm{MeOH} 89 \% 68$, $\mathrm{f}$ : pyridine $110{ }^{\circ} \mathrm{C}, 2 \mathrm{~h}, 62 \% 58 \mathrm{dr} 95: 5$. TMEDA: tetramethyl ethylene di-

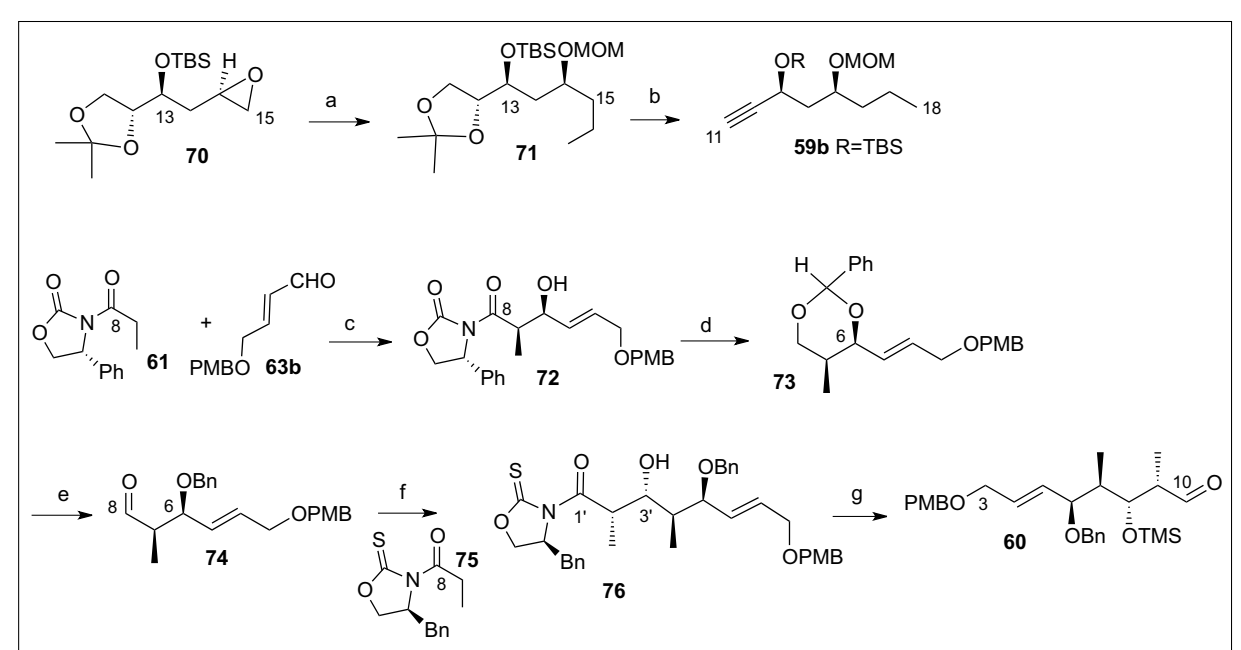

Scheme 12. Wu's preparation of subunits 59 and 60 of the larger fragment 57 of pamamycin $621 \mathrm{~A}$ (1c). Reagents and conditions: a: (i) EtMgBr/CuCN, THF, $-10^{\circ} \mathrm{C}$, (ii) $\mathrm{MOMCl}$, Hünig base, $94 \% 71$ over two steps; b: (i) TFA/water, $\mathrm{CH}_{2} \mathrm{Cl}_{2}$, (ii) $\mathrm{NalO}$ /silica gel/ $\mathrm{CH}_{2} \mathrm{Cl}_{2}$-water, (iii) $\mathrm{Ph}_{3} \mathrm{P} / \mathrm{CBr}_{4}, \mathrm{CH}_{2} \mathrm{Cl}_{2}$, (iv) $n$-BuLi, THF, $-10^{\circ} \mathrm{C}, 81 \% 59$ from 71; c: TiCl ${ }_{4}$, TMEDA, $84 \% 72$ (dr 20:1); d: (i) $\mathrm{NaBH}_{4}$, THF/ water $0{ }^{\circ} \mathrm{C}$ to rt, (ii) $\mathrm{PhCH}(\mathrm{OMe})_{2}, \mathrm{CSA}, 85 \%$ 73; e: (i) $\mathrm{DIBAL}-\mathrm{H}, \mathrm{CH}_{2} \mathrm{Cl}_{2} 0{ }^{\circ} \mathrm{C}$ to rt, (ii) Dess-Martin periodinane, $\mathrm{CH}_{2} \mathrm{Cl}_{2}, \mathrm{NaHCO}_{3} 89 \% 74$ over two steps; f: $\mathrm{TiCl}_{4}, \mathrm{CH}_{2} \mathrm{Cl}_{2}$, (-)-sparteine, $-78{ }^{\circ} \mathrm{C}, 2 \mathrm{~h}$, 94\% 76, (dr 95.5); g: (i) TMSCI, 2,6-lutidine, DMF, (ii) DIBAL-H, $\mathrm{CH}_{2} \mathrm{Cl}_{2}, 95 \% 60$ over two steps. 


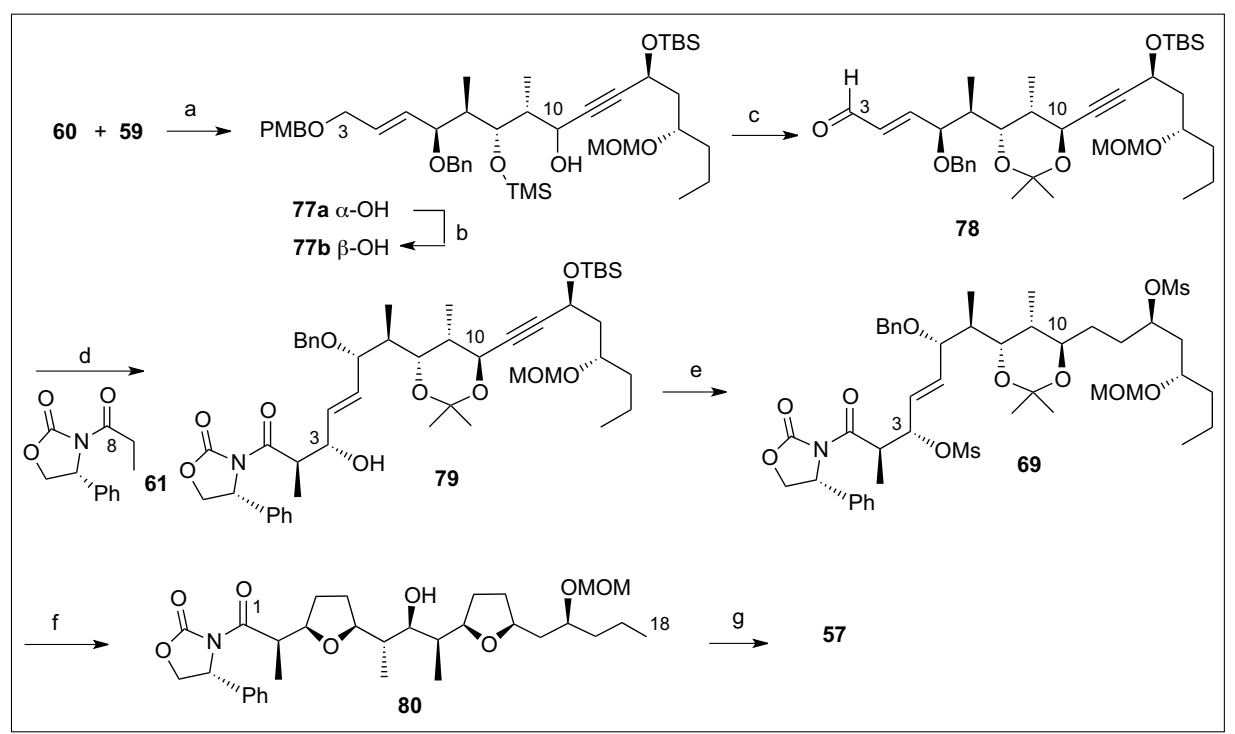

Scheme 13. Wu's preparation of the larger fragment 57 of pamamycin $621 \mathrm{~A}(\mathbf{1 c})$. Reagents and conditions: a: $n$-BuLi, THF, $-20{ }^{\circ} \mathrm{C}, 100 \%$ 77a/77b (2:3); b: Dess-Martin periodinane, (ii) L-selectride, THF, $-78{ }^{\circ} \mathrm{C}, 88 \% \mathbf{7 7 b}$ over two steps; c: (i) $\mathrm{TFA} / \mathrm{CH}_{2} \mathrm{Cl}_{2} 50 \%$, rt, (ii) $\mathrm{Me}_{2} \mathrm{C}(\mathrm{OMe})_{2} /$ PPTS, $\mathrm{CH}_{2} \mathrm{Cl}_{2}$, (iii) $\mathrm{CH}_{2} \mathrm{Cl}_{2}$ buffer (pH 7) 10:1, DDQ, (iv) Dess-Martin periodinane, 85\% 78 from 77b; d: $\mathrm{TiCl}_{4} / \mathrm{TMEDA}, \mathrm{CH}_{2} \mathrm{Cl}_{2}$, rt, 90\% 79 (dr 23:1); e: (i) HF-pyr, THF, rt, (ii) $\mathrm{H}_{2} / \mathrm{Pd}-\mathrm{C}, \mathrm{EtOAc}_{2} \mathrm{Et}_{3} \mathrm{~N}$, (iii) $\mathrm{MsCl}, \mathrm{Et}_{3} \mathrm{~N}, \mathrm{CH}_{2} \mathrm{Cl}_{2}$, rt $84 \% 69$ over three steps; f: (i) $\mathrm{TFA} \mathrm{CH}_{2} \mathrm{Cl}_{2} 50 \%$, rt, (ii) $\mathrm{H}_{2} / \mathrm{Pd}-\mathrm{C}$, THF, rt, (iii) 2,6-lutidine, $120^{\circ} \mathrm{C}, 2 \mathrm{~h}, 93 \% 80$ over three steps, g: $\mathrm{H}_{2} \mathrm{O}_{2} / \mathrm{LiOH}$, THF, rt, $94 \% 57$. PPTS = $p$ tolylsulfonic acid.

afforded the desired aldehyde $\mathbf{6 0}$. The latter was quite instable and was immediately reacted with the lithium alkynylide of $\mathbf{5 9 b}$ to produce a separable mixture (2:3) of $\mathbf{7 7 a}$ and 77b (Scheme 13).

The undesired isomer 77a could be converted into $\mathbf{7 7 b}$ by an oxidation-reduction sequence. Aldehyde 78, needed to control the $\mathrm{C}(2)$ and $\mathrm{C}(3)$ stereogenic centers in the backbone of the large fragment via Crimmins aldolization, was prepared from $\mathbf{7 7 b}$ by sequentially (i) removing the TMS protecting group, (ii) protecting the 1,3-diol as an acetonide, (iii) cleaving the para-methoxybenzyl ether, and (iv) oxidizing the resulting primary alcohol using Dess-Martin periodinane. Treatment of $\mathbf{7 8}$ with the titanium enolate of oxazolidinone 61 in the presence of TMEDA gave adduct 79 with a good isolated yield. After removal of the silyl protecting group on the homopropargylic alcohol with HF-pyr, the alkene and alkyne were hydrogenated and the two secondary alcohols were mesylated to afford intermediate 69. Cleavage of the ketal protecting group in $\mathbf{6 9}$ using $50 \%$ aqueous TFA followed by hydrogenolysis of the benzyl protecting group gave, after heating with 2,6-lutidine and subsequent treatment with hydrogen peroxide and lithium, the larger fragment of pamamycin $621 \mathrm{~A} \mathrm{(57)}$ as pure compound.

The coupling of $\mathbf{5 7}$ and $\mathbf{5 8}$ under Yamaguchi conditions followed by treatment of the resulting seco-oxazolidinone with $\mathrm{H}_{2} \mathrm{O}_{2} / \mathrm{LiOH}$ to remove the chiral auxiliary gave compound $\mathbf{8 1}$ (Scheme 14). The macrodiolide was then closed using another Yamaguchi esterification at higher temperature to give $\mathbf{8 2}$. The acetal protecting group was then removed with $10 \%$ of $\mathrm{HBr}$ solution and the deprotected alcohol at $\mathrm{C}(15)$ was converted into an azide with inversion of configuration using triphenylphosphine, DEAD, and diphenyl azido$\mathrm{CH}_{3} \mathrm{CN}, 82 \% 1 \mathrm{c}$.

phosphonate to introduce an azido group at $\mathrm{C}(15)$ with concurrent inversion of the configuration. The unexpectedly difficult azide reduction was finally achieved using tributyltin hydride in refluxing toluene in the absence of any added radical initiators. The resulting amine was methylated using standard reductive amination conditions to give pamamycin $621 \mathrm{~A}(\mathbf{1 c})$.

\section{Thomas' Total Synthesis of Pama- mycin $607(1 b)^{[27]}$}

Ten years after a preliminary communication on the first total synthesis of pamamycin 607 (1b), [7,9] E. J. Thomas reported a full description of the same synthesis along with methyl nonactate using an intramolecular selenoetherification of $(Z)$-homoallylic alcohols. The desired 1,5-anti isomers of the latter were prepared stereoselectively by a $\mathrm{SnCl}_{4}$-promoted addition of 4-methyl-5-alkoxy-2-pentenylstannanes to the requisite aldehydes. This method displayed a high level of remote asymmetric induction. ${ }^{[27]}$

\section{Biological Activity and Structure- Activity Relationships}

As mentioned previously, in addition to their complex structures, the synthetic efforts towards the pamamycins have also been fuelled by their biological activity. The more recent results (after 2005) are summarized below. In this context, Natsume and coworkers ${ }^{[28]}$ recently examined the effect of pamamycin 607 (1b) on antibiotic production by several Streptomyces spp. They observed that this macrodiolide increased the puromycin production by 2.7 fold in the pamamycin producer, $S$. alboniger NBRC 12738, and also increased the synthesis of streptomycin by 1.5 fold in $S$.

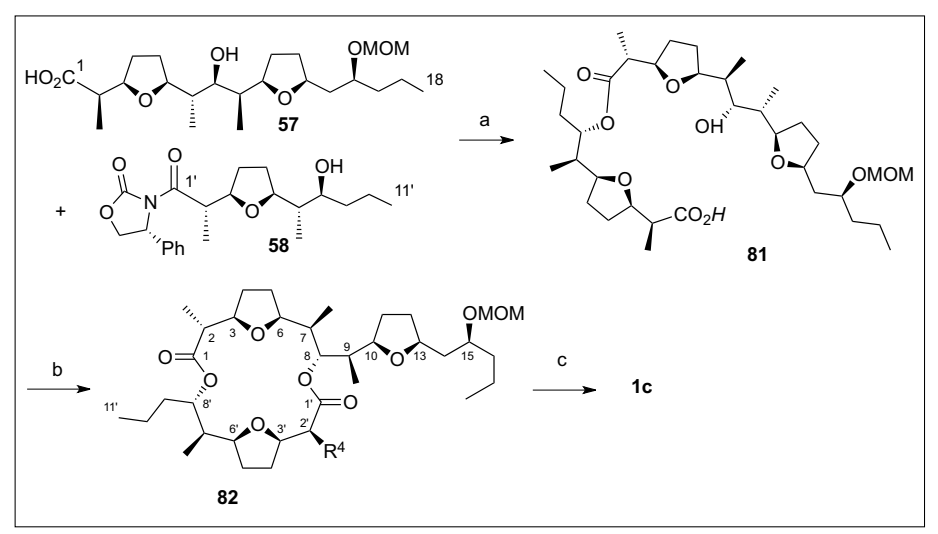

Scheme 14. Endgame of Wu's total synthesis of pamamycin 621A (1c). Reagents and conditions: a: (i) 2,4,6-trichlorobenzoyl chloride, DMAP, MS $4 \mathrm{~A}, \mathrm{CH}_{2} \mathrm{Cl}_{2}$, rt, (ii) $\mathrm{H}_{2} \mathrm{O}_{2} / \mathrm{LiOH}$, THF, rt, $80 \%$ 81; b: 2,4,6-trichlorobenzoyl chloride (20 equiv.), DMAP (20 equiv.)/ $\mathrm{NEt}_{3}$ (20 equiv.), toluene, $110{ }^{\circ} \mathrm{C}$, $66 \%$ 82; c: (i) $10 \% \mathrm{HBr}$ in $\mathrm{CH}_{3} \mathrm{CN}$, (ii) $\mathrm{PPh}_{3} / \mathrm{DEAD}$, (PhO) $\mathrm{P}(\mathrm{O}) \mathrm{N}_{3}$, THF, rt, (iii) $n-\mathrm{Bu}_{3} \mathrm{SnH}$, toluene, reflux, $2 \mathrm{~h}$, (iv) $\mathrm{NaBH}_{3} \mathrm{CN}, \mathrm{AcOH}, 37 \% \mathrm{HCHO}$

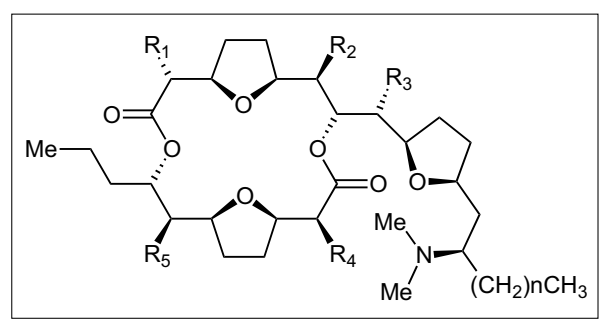

Fig. 2. Pamamycin analogues used in the structure-activity relationship. 
griseus NBRC 12875 and that of cinerubins A and B by $S$. tauricus JCM 4837 by 1.7 and 1.9 fold. Finally, pamamycin 607 enhanced 2.6 fold the production of the antibiotic virginiamycin $\mathrm{M}_{1}$, synthesized by Streptomyces sp. 91-a. Pamamycin 607's mode of action in this context has not yet been elucidated.

The structure-activity relationship of pamamycins has mainly been studied by Natsume et al. In a recent report, ${ }^{[29]}$ they determined the effect of side chain length on aerial mycelium-inducing activity by isolating two pamamycin side chain homologues from Streptomyces sp HKI-0118: homopamamycin-621A $\left(\mathrm{R}_{1}-\mathrm{R}_{5}\right.$ identical to $\mathbf{1 b}, \mathrm{n}=3$, Fig. 2) and bishomopamamycin-635A $\left(\mathrm{R}_{1}-\mathrm{R}_{5}\right.$ identical to $\mathbf{1 b}, \mathrm{n}=$ 4, Fig. 2). Taking into account this study, they summarized the structure-activity relationship of pamamycins published by them and other authors in the recent years. Thus, opening of the macrodiolide ring or scission into two constituent hydroxyl acids results in a marked drop in activity. The amine group is indispensable to aerial mycelium-inducing activity and $N$-demethylation increases this activity 1.5 times. Substitution of methyl group $R_{1}$ with an ethyl group or hydrogens $\mathrm{R}_{2}$ and $\mathrm{R}_{5}$ by a methyl group decreased the activity by ca. $1 / 10$. Substitution of the methyl group at $\mathrm{R}_{3}$ or $R_{4}$ with an ethyl group resulted in a sharp decrease in activity. Finally, the side chain homologue homopamamycin-621A $(n=3)$ exhibited only $1 / 10$ th of the original activity and bishomopamamycin-635A $(n=4)$ was found to be inactive.

Even if in the current state of things pamamycins cannot be considered as potential drugs, the oral bioavailability of two pamamycin analogues has been discussed in the literature. Indeed, Lipinski's rule of five is a rule of thumb to evaluate drug-likeness or determine a chemical compound with a certain pharmacological or biological activity that would be likely to be an orally active drug in humans. Belaidi's team ${ }^{[30]}$ has shown that pamamycins 607 and 621 do not obey the Lipinski rule. Thus, even if they don't have any hydrogen bond donors and less than 10 hydrogen bond acceptors, their molecular mass is superior to $500 \mathrm{Da}$ (607.87 and 621.90) and their calculated octanol-water partition coefficient $(\log \mathrm{P})$ is greater than 5 (5.36 and 5.86). In general, orally active drugs have no more than one violation of Lipinski's rule. The two violations for pamamycins 607 suggest that these compounds theoretically would have problems with oral bioavailability.

\section{Biosynthesis of Pamamycins}

Natsume et al. studied the biosynthetic origins of the carbon skeleton and nitrogen atom of pamamycin 607 by feeding experiments with ${ }^{13} \mathrm{C}$-acetate or -propionate, $\mathrm{L}$ $\left[{ }^{15} \mathrm{~N}\right]$ glutamic acid or valine, or ${ }^{15} \mathrm{NH}_{4} \mathrm{Cl}$ in Streptomyces alboniger in 2005. [31] Results show that the carbon skeleton of pamamycin 607 is derived from six acetate, four propionate and three succinate units. By MS analyses of ${ }^{15} \mathrm{~N}$-labeled pamamycin 607 it was demonstrated that the nitrogen atom of the dimethylamino group present in pamamycins is derived from the $\alpha$-amino group of an amino acid which has been introduced into the pamamycin structure by transamination, followed by $\mathrm{N}$-methylation. The same authors have investigated the nitrogen incorporation in the biosynthetic pathway of pamamycin using blocked mutants in Streptomyces alboni- ger. ${ }^{[32]}$ They concluded that the amination and methylation occur before the closure of the macrodiolide ring.

Very recently Metz, Petzke and Luzhetskyy elucidated the biosynthesis of the pamamycins (1) by studying the enzyme(s) that incorporate succinate. [3] They identified a pamamycin biosynthesis gene cluster by aligning genomes of two pamamycin-producing strains. This unique cluster contains polyketide synthase (PKS) genes encoding seven discrete ketosynthase (KS) enzymes and one acyl-carrier protein (ACP)-encoding gene. A cosmid containing the entire set of genes required for pamamycin biosynthesis was successfully expressed in a heterologous host. Genetic and biochemical studies allowed complete delineation of pamamycin biosynthesis. Thus, as depicted in Scheme 15, the pathway commences with the formation of the key compounds 4-oxoadipyl-CoA and

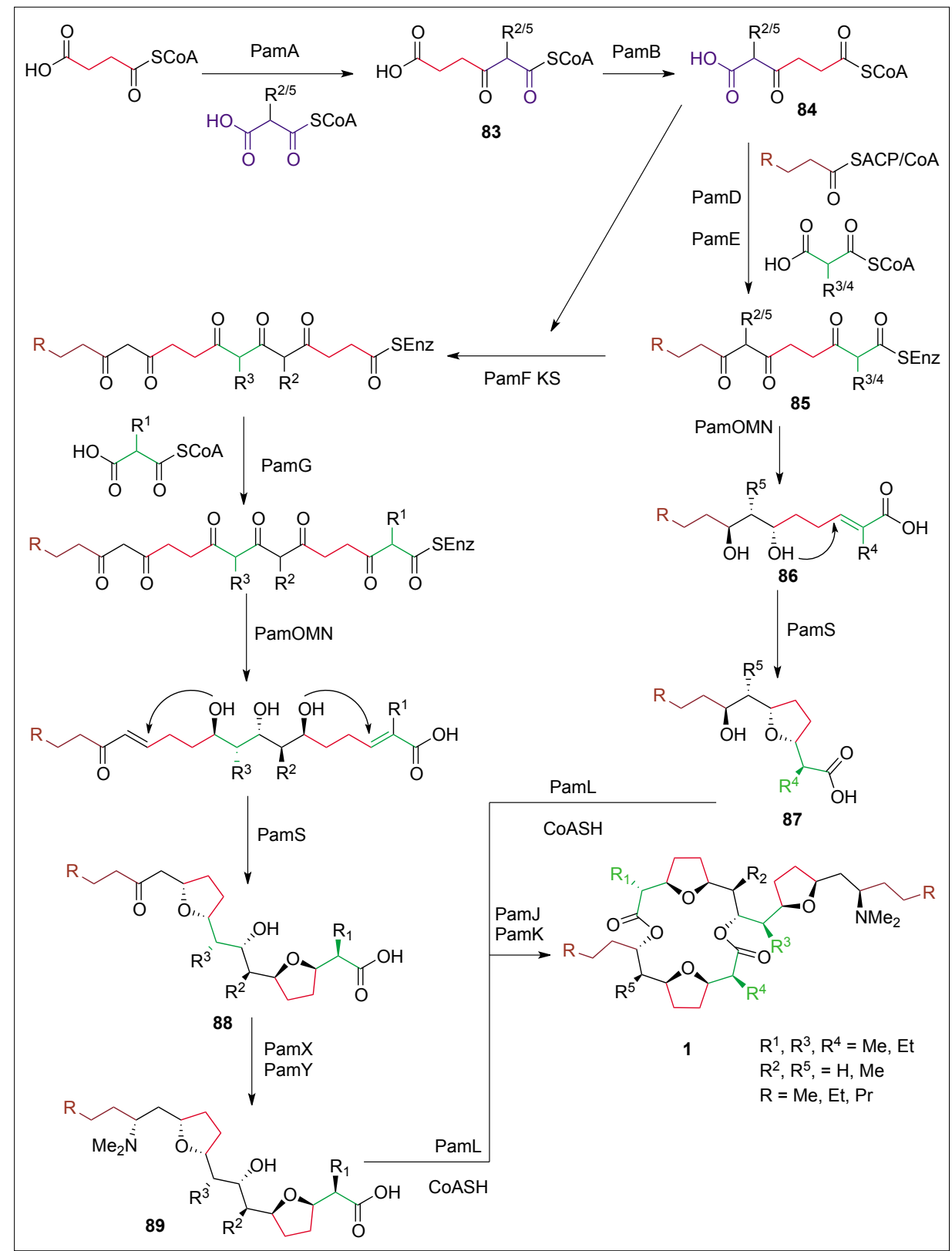

Scheme 15. Proposed biosynthetic pathway of pamamycins (1). 
5-methyl-4-oxoadipyl-CoA 83 in a condensation reaction that involves either malonyl- or methylmalonyl-CoA reacting with succinyl-CoA and is catalyzed by a PamA. The subsequent rotation of compounds $\mathbf{8 3}$ by PamB acyltransferase afforded $\mathbf{8 4}$. The carbon chain of intermediates $\mathbf{8 4}$ are then extended twice: first with a short-chain acyl, supplied probably as ACP-ester, under PamD catalysis and then by the addition of malonyl-CoA under PamE catalysis by a Claisen-type condensation leading to intermediate $\mathbf{8 5}$. Then, from compound $\mathbf{8 5}$, the biosynthetic pathway splits into two parallel routes. On the one hand, intermediate $\mathbf{8 5}$ is transformed by $\mathrm{KRs} \mathrm{PamO}, \mathrm{M}$, and $\mathrm{N}$ into the unsaturated diol 86. Intramolecular cyclization to the corresponding THF ring catalyzed by PamS, leads to the production of $\mathbf{8 7}$. On the other hand, the addition of an additional adipate 84 catalyzed by PamF to intermediate $\mathbf{8 5}$ precedes the completion of the carbon chain via condensation of malonate catalyzed by PamG. After ketone group reductions, two dehydrations and two 1,4 intramolecular additions catalyzed by $\mathrm{PamO}, \mathrm{M}$, $\mathrm{N}$, and $\mathrm{S}$, compound $\mathbf{8 8}$ bearing two tetrahydrofuran rings is obtained. Finally, $\mathbf{8 8}$ undergoes further reductive amination and methylation, respectively by Pam $\mathrm{X}$ and PamY, to afford 89. Hydroxy acids $\mathbf{8 7}$ and 89 are activated an additional time by the acyl-CoA ligase PamL. Completion of the biosynthesis of $\mathbf{1}$ is achieved by PamJ and PamK which catalyze the final cyclization involving an uncommon $\mathrm{C}-\mathrm{O}$ condensation reaction.

In addition to their unique structures, the potential uses of pamamycins have attracted a great deal of interest in the synthetic community and several total synthesis of some members of this family of macrodiolides have been published in recent years as we have detailed in the first part of this report. Nevertheless, in order to enable technical applications, methods that provide sufficient amounts of pamamycins are still necessary. In this context, since very recently, polypeptides and polynucleotides as well as gene clusters, expression cassettes and vectors comprising one or several of those polynucleotides for the production of pamamycins are accessible. These tools can thus be used to construct, identify and improve microorganisms having the capacity to produce one or several pamamycins, in particular pamamycin 607 (1b) and/or pamamycin 621A (1c). ${ }^{[4]}$

Received: September 30, 2015

[1] a) P. A. McCann, B. M. Pogell, J. Antibiot. 1979, 32, 673; b) S. Kondo, K. Yasui, M. Natsume, M. Katayama, S. Marumo, J. Antibiot. 1988, 41, 1196; c) P. Lefevre, P. Peirs, M. Braibant, M. Fauville-Dufaux, R. Vanhoof, K. Huygen, X. M. Wang, B. Pogell, Y. Wang, P. Fischer, P. Metz, J. Content, J. Antimicrob. Chemother. 2004, 54, 824.

[2] a) M. Natsume, K. Yasui, S. Kondo, S. Marumo, Tetrahedron Lett. 1991, 32, 3087; b) M. Natsume, J. Tazawa, K. Yagi, H. Abe, S. Kondo, S. Marumo, J. Antibiot. 1995, 48, 1159; c) I. Kozone, N. Chikamoto, H. Abe, M. Natsume, $J$. Antibiot. 1999, 52, 329.

[3] Y. Rebets, E. Brötz, N. Manderscheid, B. Tokovenko, M. Myronovskyi, P. Metz, L. Petzke, A. Luzhetskyy, Angew. Chem. Int. Ed. 2015, 54, 2280 .

[4] L. Petzke, A. Herold, C. Fleck, K. TreierMarxen, P. Odman, J. Dickhaut, M. Weingarten, A. Luzhetskyy, Y. Rebets, E. Brötz, N. Manderscheid, M. Myronovskyi, 2015, WO2015/092575 A1.

[5] For reviews covering the subject prior to 2005 , see: a) P. Metz, Top. Curr. Chem. 2005, 244, 215; b) E. J. Kang, E. Lee, Chem. Rev. 2005, 105,4348 .

[6] a) $\mathrm{C}\left(1^{\prime}\right)-\mathrm{C}\left(11^{\prime}\right)$ fragment of pamamycin 635A: A. Miura, H. Kiyota, S. Kuwahara, Tetrahedron 2005, 61, 1061; b) (C6-C18) domain of pamamycin 607: B.H. Fraser, R.J. Mulder, P. Perlmutter, Tetrahedron 2006, 62, 2857; c) $\mathrm{C}(1)-\mathrm{C}(18)$ fragment of Pamamycin 593 and de- $N$-methylpamamycin 579: A. Miura, S. Takigawa, Y. Furuya, Y. Yokoo, S. Kuwahara, H. Kiyota, Eur. J. Org. Chem. 2008, 4955.

[7] R. D. Walkup, G. Park, Tetrahedron Lett. 1988, 29, 5505 .

[8] O. Germay, N. Kumar, E. J. Thomas, Tetrahedron Lett. 2001, 42, 4969.
[9] P. Fischer, A. B. García Segovia, M. Gruner, P. Metz, Angew. Chem. Int. Ed. 2005, 44, 6231 .

[10] P. Fischer, M. Gruner, A. Jager, O. Kataeva, P. Metz, Chem. Eur. J. 2011, 17, 13334.

[11] a) Y. Wang, H. Bernsmann, M. Gruner, P. Metz, Tetrahedron Lett. 2001, 42, 7801; b) I. Fleming, S. K. Ghosh, J. Chem. Soc. Perkin Trans. 1 1998, 2733.

[12] S. Lanners, H. Norouzi-Arasi, X. J. SalomRoig, G. Hanquet, Angew. Chem. Int. Ed. 2007, 46, 7086.

[13] S. Lanners, H. Norouzi-Arasi, X. J. SalomRoig, G. Hanquet, to be published.

[14] G. Hanquet, F. Colobert, S. Lanners, G. Solladié, ARKIVOC 2003, vii, 328.

[15] G. Hanquet, X. J. Salom-Roig, L. GressotKempf, S. Lanners, G. Solladié, Tetrahedron: Asymm. 2003, 14, 1291.

[16] D. A. Evans, K. T. Chapman, E. M. Carreira, J. Am. Chem. Soc. 1988, 110, 3560.

[17] G. Hanquet, X. J. Salom-Roig, S. Lemeitour, G. Solladié. Eur. J. Org. Chem. 2002, 2112.

[18] a) H. C. Brown, K. Ganesan, R. K. Dhar, J. Org. Chem. 1993, 58, 147; b) H. C. Brown, K. Ganesan, J. Org. Chem. 1993, 58, 7162.

[19] S. Lanners, H. Norouzi-Arasi, N. Khiri, G. Hanquet, Eur. J. Org. Chem. 2007, 4065.

[20] D. A. Evans, A. H. Hoveyda, J. Am. Chem. Soc. 1990, 112, 6447.

[21] P. A. Bartlett, J. D. Meadows, E. Ottow, J. Am. Chem. Soc. 1984, 106, 5304.

[22] a) G. B. Ren, Y. K. Wu, Org. Lett. 2009, 11, 5638; b) G. B. Ren, Y. X. Huang, Y. P. Sun, Z. H. Li, Y. K. Wu, J. Org. Chem. 2010, 75, 5048; c) G. Ren, Y. K. Wu, Chin. J. Chem. 2010, 28, 1651.

[23] Y. K. Wu, Y. P. Sun, Org. Lett. 2006, 8, 2831.

[24] Y. K. Wu, Synlett 2013, 24, 1623.

[25] J. Mulzer, C. Pietschman, B. Schollhorn, J. Buschmann, P. Luger, Liebigs Ann. 1995, 1433.

[26] Z. J. Wu, J. Gao, G. B. Ren, Z. B. Zhen, Y. H. Zhang, Y. K. Wu, Tetrahedron 2009, 65, 289.

[27] O. Germay, N. Kumar, C. G. Moore, E. J. Thomas, Org. Biomol. Chem. 2012, 10, 9709.

[28] M. Hashimoto, H. Katsura, R. Kato, H. Kawaide, M. Natsume, Biosci. Biotechnol. Biochem. 2011, 75, 1722.

[29] I. Kozone, M. Hashimoto, U. Gräfe, H. Kawaide, H. Abe, M. Natsume, J. Antibiot. 2008, 61, 98.

[30] R. Mazri, S. Belaidi, A. Kerassa, T. Lanez, Int. Lett. Chem. Phys. Astronomy 2014, 33, 146.

[31] M. Hashimoto, H. Komatsu, I. Kozone, H. Kawaide, H. Abe, M. Natsume, Biosci. Biotechnol. Biochem. 2005, 69, 315.

[32] M. Hashimoto, I. Kozone, H. Kawaide, H. Abe, M. Natsume, J. Antibiot. 2005, 58, 722. 